Article

\title{
The Business Model Evaluation Tool for Smart Cities: Application to SmartSantander Use Cases
}

\author{
Raimundo Díaz-Díaz ${ }^{1, *}$, Luis Muñoz ${ }^{2}$ and Daniel Pérez-González ${ }^{1}$ \\ 1 Department of Business Administration, University of Cantabria, 39005 Santander, Cantabria, Spain; \\ daniel.perez@unican.es \\ 2 Department of Communications Engineering, University of Cantabria, 39005 Santander, Cantabria, Spain; \\ luis.munoz@unican.es \\ * Correspondence: raimundodiazdiaz@gmail.com; Tel.: +34-942-201497
}

Academic Editors: Mashrur Chowdhury and Kakan Dey

Received: 1 October 2016; Accepted: 4 February 2017; Published: 23 February 2017

\begin{abstract}
New technologies open up the door to multiple business models applied to public services in smart cities. However, there is not a commonly adopted methodology for evaluating business models in smart cities that can help both practitioners and researchers to choose the best option. This paper addresses this gap introducing the Business Model Evaluation Tool for Smart Cities. This methodology is a simple, organized, flexible and the transparent system that facilitates the work of the evaluators of potential business models. It is useful to compare two or more business models and take strategic decisions promptly. The method is part of a previous process of content analysis and it is based on the widely utilized Business Model Canvas. The evaluation method has been assessed by 11 experts and, subsequently it has been validated applying it to the case studies of Santander's waste management and street lighting systems, which take advantage of innovative technologies commonly used in smart cities.
\end{abstract}

Keywords: business models; performance; measurement; smart city; public service; IoT

\section{Introduction}

Global urban population is expected to reach nearly $60 \%$ of the total population in 2020 [1]. Furthermore, between 2000 and 2050 urban surface needs will be multiplied by a factor of 2 in developed countries and expanded by $326 \%$ in developing countries to fit population demands [2]. Local governments will have to manage this growth and it will put severe strain on municipal finances [3]. Therefore, city planning is getting more and more critical [4].

At the same time, there is a wave of technologies applicable to urban management. Information and Communications Technology (hereinafter referred to as ICT) should be used for an efficient and sustainable city management [5]. The concept of smart cities has emerged in this context and has gained a lot of interest amongst public managers, corporate executives, entrepreneurs and academics [6].

Cities today face increasing challenges when it comes to providing public services with innovative technologies [7]. Those responsible for carrying out smart city projects have to deal with the difficult decision of choosing the suitable systems for their city. From an academic point of view, a few methodologies for smart city management can be found in the literature [8-11]. Professionals have also moved forward and a few standardization efforts are being carried out; such is the case of the British Standards Institution (BSI), the Spanish Network of Smart Cities (its name in Spanish is Red Española de Ciudades Inteligentes) or those promoted by the International Organization for Standardization (ISO). Nevertheless, new standardization processes will have to be launched because standards are obviously slower than technology. Therefore, project leaders will be obliged to make decisions without the required knowledge. Public managers are used to making public tenders where costs or experience 
are taken into account. However, when projecting the implementation of smart technologies to public services, other elements should be measured. This is the case of business models.

Many initiatives are being carried out and the application of the Internet of Things (IoT) and other innovative technologies to the public services is a growing trend all around the world. A popular case known for its outstanding smart city research projects is Santander, a city located in the north of Spain $[10,12-19]$. This city is a significant world leader in research and development of technologies for urban management since the start of SmartSantander in 2009. This research project funded by the European Commission's FP7 included among its partners the Santander City Council, the University of Cantabria, Telefónica and other 12 European entities. SmartSantander proposed a unique in the world city-scale experimental research facility supporting cutting-edge applications and services for the smart city paradigm. Currently, the Santander City Council is deploying the hardware, middleware and software components aiming at supporting a new generation of the non-organic waste collection urban service that will take advantage of the IoT, big data and other innovative technologies. The system was initially designed by the researchers of the University of Cantabria with the public managers and in 2014 there was a public tender to assign the contract to the company that presented the best offer. The system will use more than 1000 sensors to retrieve the status of the discharge points (waste containers and bins). Additionally, both the collection vehicles and other cleaning devices will have appliances that gather information about the route followed, the activity carried out and the time involved. Container sensor data will be transmitted to the data management center, where it will be processed and subsequently transmitted to the company that provides the waste management service. The collected data will allow planning more efficient collection routes according to the location of full containers, instead of the predefined routes existing in the legacy service. The objective is that the City Council should reduce the service costs around $20 \%$ per year compared to the previous tender.

The Santander City Council is also planning to renew the street lighting facility that will rely on the use of 23,000 luminaires of light-emitting diode (LED) technology, the integration of a point-to-point monitoring and command system, and the installation of 60 points of presence to regulate the light intensity level depending on whether or not pedestrians or vehicles are detected. The public tender for the street lighting infrastructure has been recently launched and the company awarded, as well as the system that it will implement, is already known. The concessionaire has committed to achieve savings of $80 \%$ on current energy consumption, which adds a reduction of about $35 \%$ of the costs of maintenance of the service. The concessionaire will have to make an initial investment of 11 million euros to renew the facility. The return of investment for the company will come from the savings achieved in the power consumption. Before launching the public tender, a testbed had been developed in the city with the support of a research group of the University of Cantabria in order to assess the sensor detection system.

Different stakeholders are involved in the development of smart cities because of the appearance of brand new technologies, financial restrictions, and a wave of new ways of managing the commons. Local governments have been elected to lead cities but all the stakeholders are involved in that task [20-22]. In the process of evolving towards smart cities, municipalities move from traditional business models that are managed by the local government and budgeted by a third party (usually the taxpayer paying taxes) to models that boost complex relationships between the stakeholders and different financial systems like advertising or recycled materials. Bringing smart solutions to life and making them financially viable requires a proper understanding of the genuine business opportunities which may be created [23].

Innovation in business models is not a trend exclusive to smart cities; many organizations of various industries are trying different combinations of business models [24]. Nevertheless, so far there are limited studies that focus on business models and business model innovation measurability [25].

There are some tools to measure smart cities performance $[12,23,26-33]$ as well as the performance of the public services provided in smart cities [34]. An evaluation method for business models in smart cities can be found in the literature [35]. It is based on a framework [36-38] which allows a thorough 
analysis of business models in the smart city environment. This method has not been adopted by practitioners as we have not found it mentioned out of the research community, perhaps due to its complexity, a positive characteristic for that advanced users that pursue a thorough analysis but a limitation for those who are not that used to academic tools. A methodology that all the stakeholders could understand and use nimbly might be a useful contribution and that is the main objective of this paper.

In order to help public officials choose a convenient business model for a public service to be carried out in the smart cities environment, we have conceived the Business Model Evaluation Tool for Smart Cities, a method that we introduce and explain in next sections applied to waste management and street lighting urban services in Santander. It will be elaborated why this approach sounds more convenient making also the business model analysis easier and more transparent.

The rest of the paper is structured as follows: Section 2 introduces some issues around smart cities: the public services, the analysis of public services and the business models. In Section 3 the methodology used to develop the Evaluation Tool is presented. Section 4 is devoted to analyze the results of the case studies developed. In Section 5 the main results are explained and in Section 6 we report the conclusions, the limitation of our research and we propose lines for future work.

\section{State of the Art}

\subsection{Concept of Smart City}

Among both academics and practitioners, the term smart city has been so spoken about during the last few years that it is going from trend [39] to mainstream [40]. Nevertheless, there is still no agreement among academics about the meaning of the concept [34]. Some authors advocate for a definition of a smart city which links technology to the improvement of the quality of life in the city [41,42], whereas others support a definition focused on the quality of life of the citizens which recognize that ICT is a useful tool but it is not an indispensable element [34,43]. This second group of authors is closer to our positions, and we use Giffinger's definition as it is operative for our research: A forward-looking city performing well in economy, people, governance, mobility, environment, and living, built on the smart combination of endowments and activities of self-decisive, independent and aware citizens [44].

\subsection{Public Services in Smart Cities}

Many of the smart city projects that are currently being carried out depict the development of new or improved public services [45]. Furthermore, the term smart city is usually linked to the use of intelligent solutions which allow modern cities to enhance the quality of the services provided to citizens [44]. A wide range of public services can be deployed as part of smart city initiatives, including transportation, environment, building, education, tourism, healthcare, public safety [23].

The different stakeholders take a participative role in the development of public services in smart cities [14]. Not only does the involvement of the private sector grow in models like Public Private Partnership [46], but citizens also participate [47], for example, entering into conversations with the government during the process of designing the services [48] or even developing applications for community use. Public administrations usually fuel this ecosystem [49]. This kind of approach helps to transpose the citizen's needs into services that truly match their necessities [50].

\subsection{Evaluation of Public Services}

Evaluation of business performance is a task widely adopted by managers in the private sector [51]. It is important in different areas of management [52]. Performance metrics are variables or indicators that express the effectiveness and/or efficiency of a system or activity [53]. Metrics are used to implement strategy, manage operations and track performance over time [54]. Among performance measurement tools, the Balanced Scorecard (BSC) seems to be the most visible in the private sector [55] 
whereas in the public sector the Logical Framework and the Result-Based Management is broadly used [56]. These tools are not only useful for evaluation, they also serve as analytics methods to document project results, provide sound monitoring and support project planning [57].

The Public Sector has been involved in a vast trend of reform and modernization, inspired especially to the New Public Management (NPM) in the 1980s [58]. The NPM proposed solutions for reinventing, modernizing and improving the public management through the adoption of instruments from the business world [59-61]. The public sector was opened up to greater private sector influence which is reflected in the promotion of various types of relationships with private firms and the development of complex performance management systems that entails a customer service orientation [62].

Establishing, assessing, and improving the performance of public services has become an increasing obsession of governments [63]. Evaluation provides the public sector with useful information for the improvement of management performance, accountability and transparency $[64,65]$. Evaluation potentially provides the key to improved effectiveness at both organizational and policy levels as defined in terms of capacity to satisfy needs and improve the citizen's quality of life [61].

When speaking about public administrations, evaluation has been defined as the systematic measurement of the operation or impact of a political program, compared with implicit and explicit standards in order to contribute to its improvement [66]. In this context, various methods for evaluating the quality of public services have been developed [67], many of them being adaptations of previous tools created for private entities.

Most methods which evaluate public service management give more importance to analyzing its financial cost than the quality of the service provided. Very few take into account other benefits considered more ambitious like social justice [61] which shape the three dimensions of corporate sustainability: economic, environmental and social [68]. However, local governments have to consider not only cost efficiency, but also other outcomes like the quality of the service provided to the citizens in itself, environmental impact, social issues, etc. These other values are gathered in the term 'public value' [60]. Public value is defined as "what the public values and what adds value to the public sphere" [69]. These 'not economic factors' that need to be incorporated are not measureable in the traditional sense [21].

Policy makers need both objective and subjective indicators in order to evaluate the status of public management performance: though subjective indicators have their limitations, objective indicators also labor under serious shortcomings [70]. The objective approach is focused on measuring facts based on explicit criteria [71] and subjective indicators measure soft matters such as satisfaction, usually with polls [70]. Subjective indicators are sometimes necessary in business forecasting [72] and business model evaluation [72-74]. When objective and subjective indicators are combined, the analyses are more thorough [72].

The awareness about the need to improve the management of public services has grown in the last few years, especially in those provided by municipalities [23]. Local public administrations are subject to very demanding expectations of the citizens regarding the public service to be provided and therefore, it is essential to evaluate this work $[75,76]$.

Within the area of research focused on city management, many authors have studied the performance of cities [1,77-80], the measurement of smart cities in general [23,81], and the public services of smart cities in particular [12,32]. A successful smart city needs an adequate performance measurement system [39] as it allows to make the adequate strategic decisions [82].

\subsection{Business Models Analysis}

The notion of Business Model has been used since the 1960s [83] and has received a lot of attention since the 1990s [84]. It has been approached from different fields such as e-business, information systems, computer science, strategy or management [85]. The business model concept offers managers a coherent way to consider their options in uncertain, fast-moving and unpredictable environments [86]. 
Many definitions can be found in literature focusing the approach on business strategy [87] useful for our research purpose. Amongst the most cited in the literature is the one given by Osterwalder and Pigneur [88] who consider that business models describe the rationale of how an organization creates, delivers and captures value.

Innovations can be regarded as products, services or processes which were not available before, or which differ significantly from existing products and services [89]. Performance measurement systems are required to control and plan innovation [89]. Business model innovation describes the design process for giving birth to a fairly new business model on the market, which is accompanied by an adjustment of the value proposition and/or the value constellation and aims at generating or securing a sustainable competitive advantage [90].

Many tools which assist companies to define, evaluate or plan the implementation of business models are found in literature [84,91,92]. Osterwalder's Business Model Canvas has become the most famous framework for this purpose between researchers and academics $[87,93]$. This framework is a visual chart composed of nine charts describing a firm's or product's value proposition, customers, and finances. It was resumed afterwards with a deeper analysis of the value proposition chart, for which it was developed the Value Proposition Canvas [94]. Some researchers have modified a few parts of the framework for various different purposes [95]. In fact, even the developers of the Business Model Canvas presented a modified framework specially designed to analyze the business model of non-profit organizations which they also recommend for public administrations [88] as when analyzing public services, the public value should also be taken in account [23]. The main difference between the Non-Profit Business Model Canvas and the original Canvas is that the first one includes two additional parameters, "Social and Environmental Profits" and "Social and Environmental Cost" (Figure 1). These new parameters are used to collect a number of not purely economic values that are important when making decisions that affect the society.

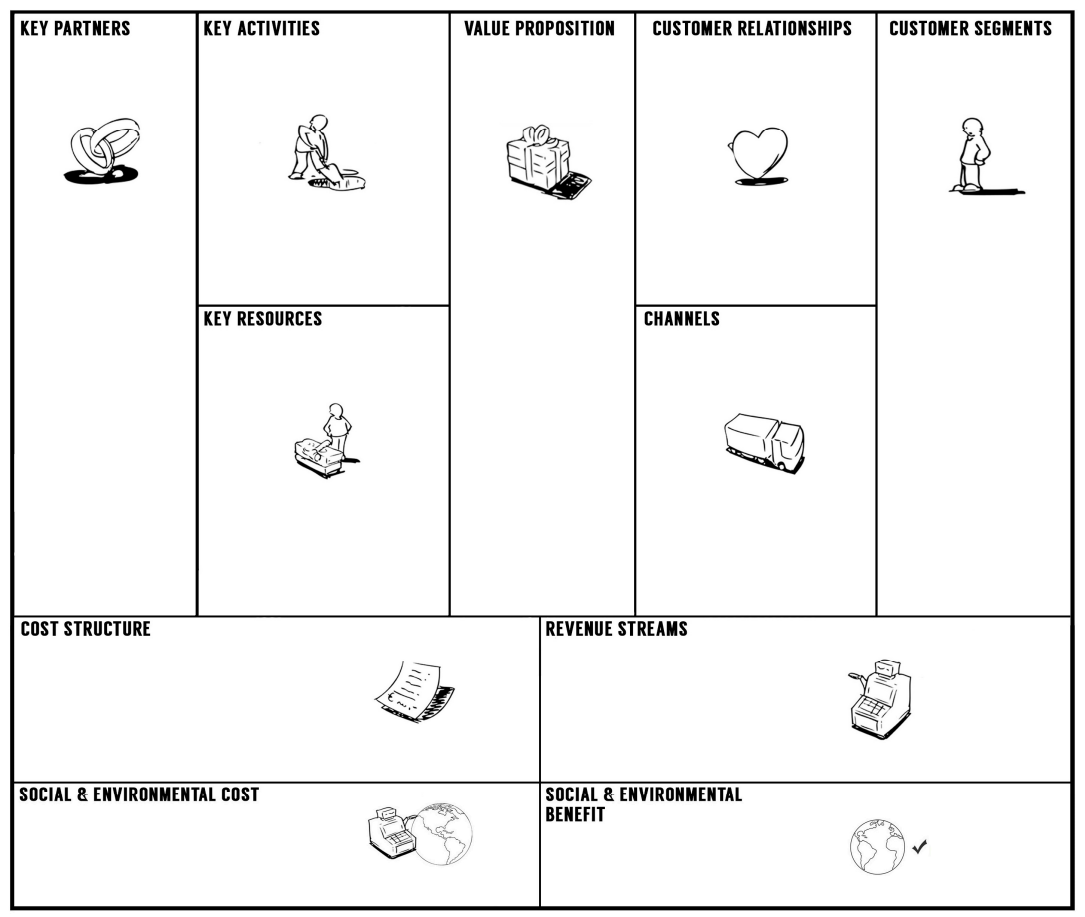

Figure 1. Non-Profit Business Model Canvas [88].

Performance measurement is key in business strategy [52] and it is also needed in the field of business model analysis [54]. However, although some have been developed for this purpose [96], 
there is actually a gap in literature relating to performance measurement of collaborative business models [97,98].

\subsection{Application of Business Models Analysis to Smart Cities}

The term business model is commonly used in social innovation environments [91] and it has also been used to analyze companies that employ technology to create and capture value [99]. Some approaches have also been carried out in analyzing business models in IoT driven environments through the development of specific frameworks for this purpose [100-103]. Therefore, it is not surprising that the concept has also been linked to smart cities [83,104-108]. When applied to the urban context, innovative technologies leverage a disruption in the management of public services so it is necessary to design innovative business models [109].

Nevertheless, the few researchers and practitioners that have used theoretical frameworks to analyze business models in smart cities applied the traditional Canvas $[107,110]$ or created new frameworks specifically developed for this environment [36]. A paper describing a framework specifically designed to analyze business models in smart cities can be found in the literature; it uses the concepts of control and public value in order to take into account the intangible factors of the smart cities $[7,111]$. The same author has also developed a method to evaluate business models in smart cities [35].

\section{Methodology}

The objective of our work is to develop a new method for characterizing and benchmarking business models in smart cities. These kinds of frameworks are useful to try to understand how things work [112]. The research work has been developed using the constructive method. This methodology aims at solving managerial problems in business organizations through the construction of models, diagrams and plans useful to both industry practitioners and academics [113]. The process of using the constructive approach is made up of the following six steps, which may vary in order from case to case [114]:

1. Choosing a relevant practical problem with research potential

2. Obtaining pre-understanding of the topic

3. Constructing a solution idea

4. Assessing that the solution works

5. Showing theoretical connections and research contribution of the solution

6. Evaluating the scope and applicability of the solution

The constructive research steps are matched with suitable research methods and data so that the methodology reveals different angles of the research problem with a heterogeneous combination of complementary methods [114]. In our case, we have used several methodologies to conduct our research: content analysis, in-depth interviews, and case study. The complete process of the research work is illustrated in Table 1.

We analyzed research literature in the field which constitutes a content analysis method. Content analysis is a research technique which intends to be objective, systematic and quantitative in the study of the content of communications [115]. Through literature we identified the main frameworks for business model analysis and then we selected the one we considered more appropriate for smart cities, the Non Profit Business Model Canvas. Based on the selected framework and using the literature, we developed a method to evaluate business models in smart cities. This method is the main contribution of this paper. 
Table 1. Research work process.

\begin{tabular}{|c|c|c|c|c|c|}
\hline $\begin{array}{c}\text { Phase of Our } \\
\text { Research Work }\end{array}$ & 1 & 2 & 3 & 4 & 5 \\
\hline Action & Planning & Literature Review & Interviews to Experts & Case Study & $\begin{array}{c}\text { Writing of } \\
\text { Research Paper }\end{array}$ \\
\hline $\begin{array}{l}\text { Descripction of } \\
\text { the activity }\end{array}$ & $\begin{array}{l}\text { Meeting and discussion } \\
\text { among the authors }\end{array}$ & $\begin{array}{l}\text { Review of all the frameworks for } \\
\text { business model analysis published } \\
\text { in order to apply previous } \\
\text { knowledge to our method }\end{array}$ & $\begin{array}{l}11 \text { experts were asked for } \\
\text { recommendations regarding } \\
\text { the draft of the BMCETSC }\end{array}$ & $\begin{array}{c}\text { Application of the BMCETSC } \\
\text { to } 2 \text { cases studies in order to } \\
\text { prove applicability } \\
\text { and validity }\end{array}$ & $\begin{array}{l}\text { The research work carried } \\
\text { out is described in detail } \\
\text { and put on paper }\end{array}$ \\
\hline Outcome & $\begin{array}{l}\text { Definition of the problem } \\
\text { and determination of the } \\
\text { research process }\end{array}$ & $\begin{array}{l}\text { Selection of the Non-Profit Business } \\
\text { Model Canvas as the basis for our } \\
\text { work, and development of the first } \\
\text { draft of the Business Model Canvas } \\
\text { Evaluation Tool for Smart } \\
\text { Cities (BMETSC) }\end{array}$ & $\begin{array}{l}\text { Development of the final } \\
\text { version of the BMCETSC }\end{array}$ & The BMCETSC is validated & $\begin{array}{l}\text { Final paper with the } \\
\text { description of the } \\
\text { research work }\end{array}$ \\
\hline $\begin{array}{c}\text { Step of the } \\
\text { constructive method }\end{array}$ & $\begin{array}{l}\text { Step } 1 \text { of the } \\
\text { constructive method }\end{array}$ & Step 2 of the constructive method & $\begin{array}{l}\text { Steps } 3,4 \text { and } 6 \text { of the } \\
\text { constructive method }\end{array}$ & $\begin{array}{l}\text { Steps } 4 \text { and } 6 \text { of the } \\
\text { constructive method }\end{array}$ & $\begin{array}{l}\text { Steps } 3,5 \text { and } 6 \text { of the } \\
\text { constructive method }\end{array}$ \\
\hline
\end{tabular}


Afterwards, we conducted semi-structured interviews with 11 experts. The interviewees were chosen through case selection. This type of selection is used when the objective is a depth and richness of information, but not the amount nor standardization. The total number of participants is determined by saturation of categories, whereby the number of participants is restricted to units of analysis that provide novel material [116]. Interviews were conducted with local politicians (two interviewees), business managers (four interviewees), and researchers specialized in business models or public management (five interviewees). The interviewees selected represent the roles of the triple helix of innovation [117] and they all have knowledge about business models and/or smart cities (their names, organization and positions of the interviewed are available in the following note [118]). Interviews lasted an average of $60 \mathrm{~min}$. In-depth interviews are a widely used qualitative method in exploratory and social research [119]. When they are semi-structured, interviews allow flexibility, as topic lists do not need to be followed religiously and can be modified depending on the expertise or the issues raised during the conversation [120].

The experts were asked about the importance and objectives of analyzing business models in smart cities, their opinion about the existing frameworks to analyze business models, the parameters to be measured in the methodology to be developed, etc. They analyzed our methodology to evaluate business models in smart cities and then they gave some suggestions. A total of 10 interviewees considered appropriate the method we describe in this paper and only one recommended developing a different tool. We modified our first draft of the method in order to address their suggestions.

In addition, we developed case study research to validate the chosen framework. Case study research is a common method for testing theories [121]. Theoretical frameworks require a permanent verification of the reality they represent in order to be updated [122].

To assess our research and develop measures for a diverse array of sectors, we decided to choose two public services from different sectors, both operating with smart technologies: waste and street lighting management systems. We introduced two case studies since multiple-case studies provide a more solid foundation for theory building [123]. We analyzed the business models of these two case studies using the Business Model Canvas with the information collected observing how services are performing, public information available in the CKAN Open Data repository and additional information owned by the Municipality. The interviewees also gave values to the parameters related to both public services.

\section{Results}

This section is divided in three parts. First, the methodology development process to evaluate business models in smart cities is described. Second, the methodology is applied to the case study of the waste management system of the city of Santander. Third, a new application of the methodology is described in order to demonstrate that it may be applied to every use case, this time it is the street lighting infrastructure of Santander.

\subsection{Description of the Evaluation Tool for Business Model Analysis in Smart Cities}

The 11 experts interviewed expressed the desirability of developing a methodology for evaluating the business models of the public services in the smart cities. New technologies applied to urban management are opening up new possibilities for economic sustainability for cities and respondents perceive that a methodology to analyze and compare the possible business models would be useful for public administrations and companies, as well as for the research community.

We have used the Business Model Canvas for being, according to the literature $[87,93]$, the framework commonly adopted by both researchers and practitioners. In particular, we adopted the Non-Profit Business Model Canvas as it is more convenient for public administrations. 
Table 2. The Evaluation Tool for Business Model Analysis in Smart Cities.

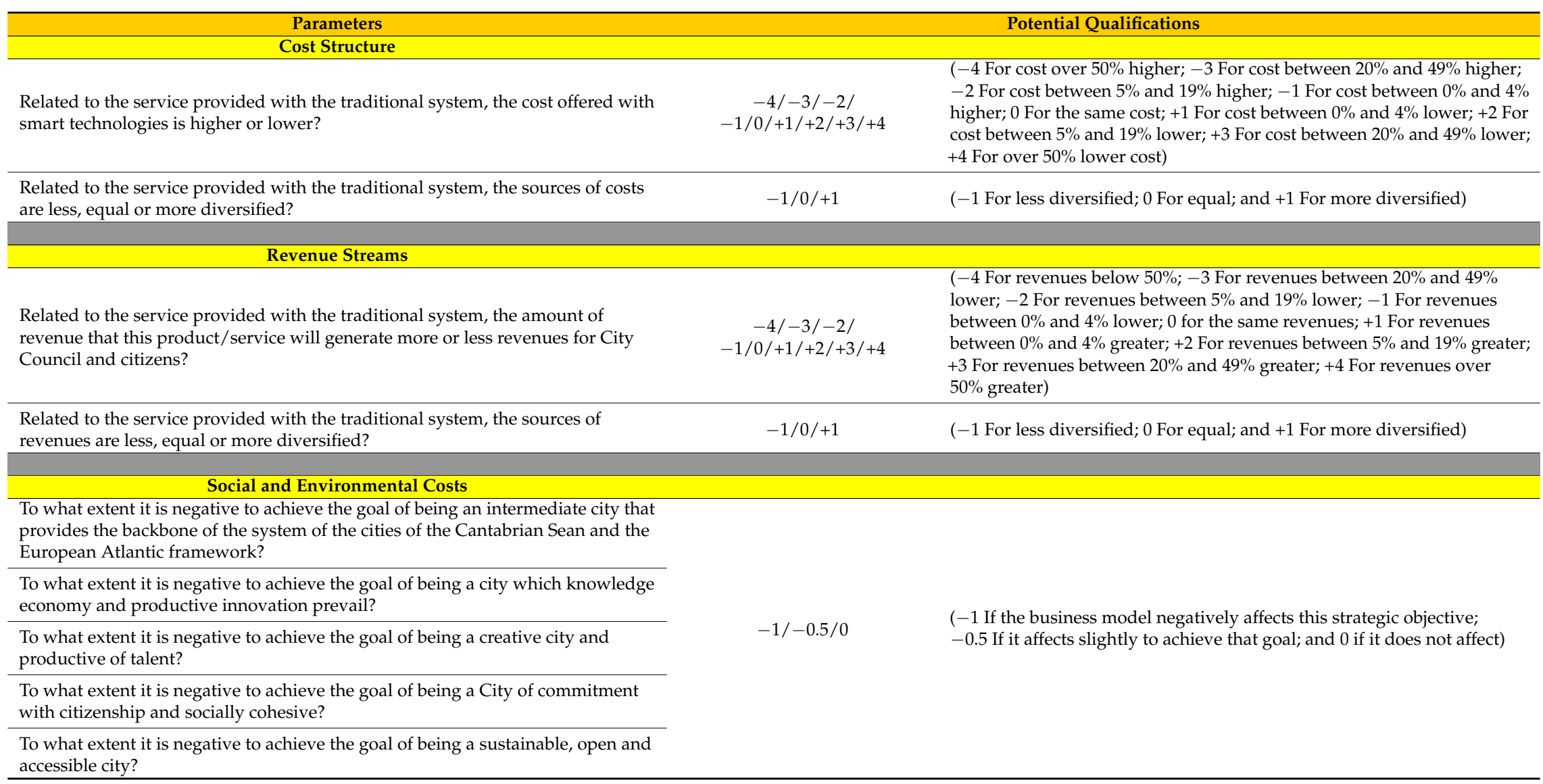


Table 2. Cont.

\begin{tabular}{|c|c|c|}
\hline Parameters & & Potential Qualifications \\
\hline Social and Environmental Benefits & \multirow{6}{*}{$0 /+0.5 /+1$} & \multirow{6}{*}{$\begin{array}{l}\text { ( } 0 \text { if the business model does not contribute to achieving this objective; } \\
+0.5 \text { If it contributes slightly to achieve that goal; and }+1 \text { if it contributes } \\
\text { a lot })\end{array}$} \\
\hline $\begin{array}{l}\text { To what extent it contributes to achieve the goal of being an intermediate city that } \\
\text { provides the backbone of the system of the cities of the Cantabrian Sean and the } \\
\text { European Atlantic framework? }\end{array}$ & & \\
\hline $\begin{array}{l}\text { To what extent it contributes to achieve the goal of being a city which knowledge } \\
\text { economy and productive innovation prevail? }\end{array}$ & & \\
\hline $\begin{array}{l}\text { To what extent it contributes to achieve the goal of being a creative city and } \\
\text { productive of talent? }\end{array}$ & & \\
\hline $\begin{array}{l}\text { To what extent it contributes to achieve the goal of being a City of commitment } \\
\text { with citizenship and socially cohesive? }\end{array}$ & & \\
\hline $\begin{array}{l}\text { To what extent it contributes to achieve the goal of being a sustainable, open and } \\
\text { accessible city? }\end{array}$ & & \\
\hline \multicolumn{3}{|l|}{$\begin{array}{ll}\text { Value Proposition } \\
\end{array}$} \\
\hline \multicolumn{2}{|l|}{ The product/service meets a need of City Council and citizens? } & \multirow{5}{*}{$\begin{array}{l}\text { ( } 0 \text { if the answer is No; }+0.5 \text { If the answer is eminently positive; and }+1 \text { if } \\
\text { the answer is clearly positive) }\end{array}$} \\
\hline Are the citizens interested in adopting this product / service? & \multirow{4}{*}{$0 /+0.5 /+1$} & \\
\hline Is this product/service a plausible improvement in the quality of life of citizens? & & \\
\hline Is the product/service of better quality than current alternatives? & & \\
\hline \multirow{2}{*}{\multicolumn{3}{|c|}{ Is the product/service's price better price than current alternatives? }} \\
\hline & & \\
\hline \multicolumn{2}{|l|}{ Is the product/service potentially beneficial to at least $1 \%$ of citizens? } & \multirow{5}{*}{ ( 0 if the answer is negative; and +1 if the answer is positive) } \\
\hline \multicolumn{2}{|l|}{ Is the product/service potentially beneficial to between $1 \%$ and $9 \%$ of citizens? } & \\
\hline Is the product/service potentially beneficial to between $10 \%$ and $24 \%$ of citizens? & $0 /+1$ & \\
\hline Is the product/service potentially beneficial to between $25 \%$ and $49 \%$ of citizens? & & \\
\hline \multicolumn{2}{|l|}{ Is the product/service potentially beneficial for more than $50 \%$ of citizens? } & \\
\hline Is the product/service potentially detrimental to at least $1 \%$ of citizens? & & \\
\hline Is the product/service potentially detrimental to between $1 \%$ and $9 \%$ of citizens? & & \\
\hline $\begin{array}{l}\text { Is the product/service potentially detrimental to between } 10 \% \text { and } 24 \% \\
\text { of citizens? }\end{array}$ & $-1 / 0$ & ( 0 if the answer is negative; and -1 if the answer is positive) \\
\hline $\begin{array}{l}\text { Is the product/service potentially detrimental to between } 25 \% \text { and } 49 \% \\
\text { of citizens? }\end{array}$ & & \\
\hline Is the product/service potentially detrimental for more than $50 \%$ of citizens? & & \\
\hline
\end{tabular}


When analyzing the business models implemented in public services, we have taken into account the point of view of the aggregation of actors, as seven respondents recommended. The local government is the main stakeholder responsible for the provision of municipal utilities, but other players in the ecosystem often participate too, such the case of a concessionaire or even proactive citizens are a couple of examples. This justifies that the business model from the point of view of the aggregation of all involved stakeholders as service providers has been take into consideration.

We developed the methodology we found most appropriate to evaluate business models in smart cities. It was also approved by 10 of the 11 respondents, who also provided some recommendations that we have applied afterwards. This paper introduces the resulting method (Table 2). The system assesses six out of the 11 parameters of Non-Profit Business Model Canvas which exhibit obvious outcomes and thus are feasible to be compared among different business models. Each parameter is evaluated on scale in which the negative figures refer to detrimental aspects for the smart city, and those positive refer to beneficial aspects. In the evaluation process, values are assigned in response to a total of 29 questions related to specific needs of each of the 6 parameters. These questions become qualitative indicators that combine objective and subjective measures.

The period taken as a reference has to be agreed before the assessment by those responsible for implementing this methodology. In the case that the service is provided on the basis of a private management model, it is usual, in terms of fixing the analysis period, to extend it to the duration of the public tender. Other reference periods are also possible, for example, the shelf life of the equipment to be invested in or the duration of its amortization.

The Business Model Evaluation Tool for Business Analysis in Smart Cities allows those who want to apply the method to benchmark the different business models to be assessed. For example, the valuator can make a comparison, both between the business model of the smart service to be implemented and the public service provided with traditional systems, as well as between different business models potentially implementable with smart technologies. The first example would assess the appropriateness of replacing a traditional public service business model with a smart technology one; the second example would help to choose the most appropriate new business model for the smart city, among the existing possibilities.

The six assessable parameters are the following:

(a) Cost Structure: This parameter of the Business Model Canvas refers to the costs involved in operating the product or service, including investment in machinery, labor, raw materials, etc. For this evaluation we have created two variables:

(a.i.) "Amount of costs that this product/service will generate for the city and the citizens", which we consider the most relevant part of the parameter and allows taking into account whether an increase in costs or net savings in the reference period occurs. It is scored as follows:

- (-4): The service provided with smart technologies has $50 \%$ higher cost than the service provided by the traditional systems.

- (-3): The service provided with smart technology is more than $20 \%$ and up to $50 \%$ more expensive than the service provided by traditional systems.

- (-2): The service provided with smart technology is over $5 \%$ and up to $20 \%$ more expensive than the service provided by the traditional systems.

- $(-1)$ : The smart service provided technology costs between $0 \%$ and $5 \%$ more than the service provided with the traditional systems.

- (0): The service is provided with smart technologies has the same cost than the service provided with the traditional systems.

- (+1): The service provided with smart technologies will cost between $0 \%$ and $5 \%$ less than the service provided by traditional systems. 
- (+2): The service provided with smart technology has a lower cost, ranging from $5 \%$ to $20 \%$ less than the service provided with traditional systems.

- (+3): The service provided with smart technology has a lower cost, which ranges from $20 \%$ to $50 \%$ less than the service provided with traditional systems.

- (+4): The service provided with smart technology has lower cost, being $50 \%$ cheaper or more than the service provided with traditional systems.

(a.ii.) "Diversification of cost sources". We believe it is an aspect to take into account because the greater the diversification, the lower the risk for the city, so we assign a numeric value as follows:

- (-1): It means that the sources are less diversified than in the service provided with traditional systems.

- (0): It is equivalent to the same diversification in the service provided with traditional systems.

- (+1): There is more diversification than in the service provided with traditional systems.

(b) Revenue Streams: The Business Model Canvas describes this parameter as the revenues generated by the product or service, and in our method we start from the perspective of the evaluation between the business models to be compared. To evaluate this parameter, we have created two variables:

(b.i.) "Amount of costs that this product/service will generate for the city and citizens", which we consider the most relevant parameter and therefore is measured as follows:

- (-4): The service provided with smart technologies generates revenues $50 \%$ lower than the service provided with traditional systems.

- (-3): The service provided with smart technologies generates revenues between $20 \%$ and $50 \%$ lower than the service provided with traditional systems.

- $\quad(-2)$ : The service provided with smart technologies has generated revenues between $5 \%$ and $20 \%$ lower than the service provided with traditional systems.

- $\quad(-1)$ : The service provided with smart technologies generated revenues between $0 \%$ and $5 \%$ lower than the service provided with traditional systems.

- (0): The service provided with smart technologies generates revenues equivalent to the service provided with traditional systems.

- (+1): The service provided with smart technologies generates revenues between $0 \%$ and $5 \%$ higher than the service provided with traditional systems.

- (+2): The service provided with smart technology generates higher revenues, ranging from $5 \%$ to $20 \%$ more than the service provided with traditional systems.

- (+3): The service provided with smart technology generates higher revenues, ranging from $20 \%$ to $50 \%$ more than the service provided with traditional systems.

- (+4): The service provided with smart technology generates revenues over $50 \%$ higher than the service provided with traditional systems.

(b.ii.) "Diversification of sources of revenues". We believe it is an aspect to consider as greater diversification brings less risk to the city. We propose a numeric value like this:

- (-1): Applied to sources less diversified than in the traditional system.

- (0): Equivalent to the same diversification in the traditional system.

- (+1): Means that there is more diversification than in the traditional system.

(c) Social and Environmental Costs: This parameter does not exist in the Business Model Canvas but it does in the Non-Profit Business Model Canvas. It refers to non-economic aspects of the 
business model that are harmful to the intelligent city. In general, these aspects are often the same in every city in the world, but municipalities have different priorities about which of them are more or less important. Therefore, we believe that the appropriate reference to assign values is the strategic plan of the city because the strategic objectives are evident on it. The assessment of social and environmental costs is made taking into account whether the business model analyzed adversely affects the strategic objectives of the city. For example, in the Santander case study we have taken the Santander Strategic Plan 2020 [124] and selected five strategic dimensions of the future vision of the city. Each dimension receives a value depending on how the business model affects that dimension according to the following assessment:

- (-1): It means that the( business model affects each strategic objective very negatively.

- $\quad(-0.5)$ : To be assigned if the business model partially affects each strategic objective.

- (0): When it does not affect the strategic objective.

(d) Social and Environmental Benefits: Just like the previous one, this parameter only exists in the Non-Profit Business Model Canvas. It refers to non-financial aspects of the business model that are beneficial for the smart city. The assignment of numerical parameter values is done by assessing how the business model analyzed contributes to the strategic objectives defined in the strategic plan of the city. In the case study we have taken the five strategic dimensions of the Strategic Plan of Santander 2020 and assigned values of 0 if the business model does not contribute to achieving this objective, 0.5 if it contributes a little, and 1 if it helps a lot.

(e) Value Proposition: This parameter makes explicit how Organizations are creating value for customers. In our methodology we have developed five questions that help assess to what extent is the business model analyzed valuable. Each question can be answered with 0 points (negative answer to that question), 0.5 points (partially positive response) or 1 point (fully positive response). These questions have been created by us, but are based on others presented in the book that introduced the Value Proposition Canvas.

(f) Customer Segments: This parameter shows for how many citizens the business model is potentially applicable, beneficial or harmful. There are five positive and five negative values that are adding or subtracting fractions of 1 point until it exceeds $50 \%$ of the population, which we consider the top as it is clearly beneficial for whole the population.

In benchmarking business models, the six parameters can be compared either separately or jointly. In order to facilitate comparisons of business models as a whole, we have designed a formula that calculates a single value for the entire business model. This formula arises from the answers given to the Evaluation Tool and its objective is to make business model benchmarking easier. We called it Value of the Business Model (VBM). This value is calculated as follows:

$$
\begin{gathered}
\text { VBM }=(C E+\text { RE }- \text { SEC }+ \text { SEB }+ \text { VP }) C S \\
\text { VBM }=\text { Value of the Business Model } \\
\text { CE }=\text { Cost Structure } \\
\text { RE }=\text { Revenue Streams } \\
\text { SEC = Social and Environmental Costs } \\
\text { SEB = Social and Environmental Benefits } \\
\text { VP = Value Proposition } \\
\text { CS = Customers Segment }
\end{gathered}
$$




\subsection{Use Case: The Waste Management System of the City of Santander}

The Santander waste management solution relies on the IoT infrastructure to collect real time information which enables to analyze huge data amounts aiming at supporting the decision making process. We analyzed the business model of the new waste management system taking as a reference point the comparison with the traditional model that has been applied so far (Table 3).

Table 3. Comparison of the business models of the conventional waste management service and the one integrating IoT infrastructure.

\begin{tabular}{|c|c|c|c|c|c|c|}
\hline \multirow{5}{*}{$\begin{array}{l}\text { KEY PARTNERS } \\
\text { - Aggregation service provi- } \\
\text { ders (City Council + Concessio- } \\
\text { naire company) } \\
\text { - Truck and container provi- } \\
\text { ders. } \\
\text { - Processing plant equipment } \\
\text { providers. } \\
\text { - Aggregation service provi- } \\
\text { ders (City Council + Concessio- } \\
\text { naire company + University of } \\
\text { Cantabria as loT infrastruc- } \\
\text { ture manager). } \\
\text { - Truck and container provi- } \\
\text { ders. } \\
\text { - Processing plant equipment } \\
\text { providers. } \\
\text { - Users, as they inform } \\
\text { about damaged containers } \\
\text { and manage personal waste } \\
\text { using the mobile applica- } \\
\text { tions. }\end{array}$} & \multirow{3}{*}{\begin{tabular}{|l|} 
KEY ACTIVITIES \\
- Waste collection. \\
- Waste processing. \\
- Recycled waste sales. \\
- Waste collection. \\
- Management of information \\
collected by sensors through the big \\
data platform. \\
- Waste processing. \\
- Recycled waste sales. \\
\end{tabular}} & \multirow{3}{*}{\multicolumn{2}{|c|}{\begin{tabular}{|l|} 
VALUE PROPOSITION \\
- Quality service for waste \\
collection. \\
- Quality service for waste \\
collection, at lower economic \\
costs and less \\
environmental impact. \\
\end{tabular}}} & \multirow{3}{*}{\multicolumn{2}{|c|}{$\begin{array}{l}\text { CUSTOMER RELATIONSHIPS } \\
\text { - Users dispose waste in containers } \\
\text { (self-service relation). } \\
\text { - Personal and exclusive assistance from } \\
\text { the Concessionaire to the City Council. } \\
\text { - Users dispose waste in containers } \\
\text { (self-service relation). } \\
\text { - Users inform about damaged } \\
\text { containers using "El pulso de la } \\
\text { ciuddad" application and managing } \\
\text { personal waste based on information } \\
\text { from the "Cuida Santander" } \\
\text { application. } \\
\text { - Personal and exclusive assistance from } \\
\text { the Concessionaire to the City Council. }\end{array}$}} & \multirow{5}{*}{$\begin{array}{l}\text { CUSTOMER SEGMENTS } \\
\text { - Users / Citizens. } \\
\text { - The City Council, as it is the } \\
\text { Concessionaire's client. } \\
\text { - The companies that buy waste } \\
\text { to process recycled waste are } \\
\text { also clients of the } \\
\text { Concessionaire. } \\
\text { - Users / Citizens. } \\
\text { - The City Council, as it is the } \\
\text { Concessionaire's client. } \\
\text { - The companies that buy waste } \\
\text { to process recycled waste are } \\
\text { also clients of the } \\
\text { Concessionaire. }\end{array}$} \\
\hline & & & & & & \\
\hline & & & & & & \\
\hline & $\begin{array}{l}\text { KEY RESOURCES } \\
\text { - Employees (dustmen and } \\
\text { administration staff). } \\
\text { - Trucks and containers. } \\
\text { - Waste processing plant. } \\
\text { - The Concessionaire's previous } \\
\text { experience in tender processes for } \\
\text { municipal waste management is an } \\
\text { asset for future public tenders. }\end{array}$ & & & $\begin{array}{l}\text { CHANNELS } \\
\text { - Promotional materials ( } \\
\text { website, brochures, adve } \\
\text { - News in the media. } \\
\text { - E-mails from the citizen } \\
\text { service at the City Counc } \\
\text { - The Concessionaire's sa } \\
\text { contact with City Council }\end{array}$ & $\begin{array}{l}\text { orporate } \\
\text { tising....). } \\
\text { information } \\
\text { es team is in }\end{array}$ & \\
\hline & $\begin{array}{l}\text { - Employees (dustmen, administration } \\
\text { staff and data managers). } \\
\text { - Sensors and data management } \\
\text { platform. } \\
\text { - loT infrastructure technicians } \\
\text { (University of Cantabria). } \\
\text { - Trucks and containers. } \\
\text { - Waste processing plant. } \\
\text { - The Concessionaire's previous } \\
\text { experience in tender processes for } \\
\text { municipal waste management is an } \\
\text { asset for future public tenders. }\end{array}$ & & & $\begin{array}{l}\text { - Promotional materials } \\
\text { website, brochures, adve } \\
\text { - - ews in the media. } \\
\text { - Public conferences, w } \\
\text { hackathons, and other } \\
\text { disclosure information } \\
\text { Santander's smart city } \\
\text { - E-mails from the citizen } \\
\text { service at the City Counc } \\
\text { - "Cuida Santander" an } \\
\text { la ciudad" mobile appli } \\
\text { citizens. } \\
\text { - The Concessionaire's sa } \\
\text { contact with City Council }\end{array}$ & $\begin{array}{l}\text { orporate } \\
\text { tising....). } \\
\text { rkshops, } \\
\text { ctivities to } \\
\text { bout } \\
\text { rojects. } \\
\text { information } \\
\text { "FI pulso de } \\
\text { ations for } \\
\text { es team is in }\end{array}$ & \\
\hline $\begin{array}{l}\text { COST STRUCTURE } \\
\text { - Employee salaries. } \\
\text { - Logistic expenditure (trucks, } \\
\text { fuel and containers) } \\
\text {-Waste processing plant. }\end{array}$ & $\begin{array}{l}\text { - Employee salaries. } \\
\text { - Logistic expenditure (trucks, fuel and co } \\
\text { platform and smart sensors). } \\
\text { - Waste processing plant. } \\
\text { - University of Cantabria's IoT infrastru } \\
\text { management cost. } \\
\text { * The initial economic investment is bi } \\
\text { greater equipment requirements, but } \\
\text { term a more efficient technology allow } \\
\text { the overall cost of the service. }\end{array}$ & $\begin{array}{l}\text { ontainers, } \\
\text { ructure service } \\
\text { igger due to } \\
\text { in the long } \\
\text { ws to reduce }\end{array}$ & $\begin{array}{l}\text { REVENUE ST } \\
\text { - The City Coun } \\
\text { to pay the Conc } \\
\text { server provider } \\
\text { - Recycled wast }\end{array}$ & $\begin{array}{l}\text { TREAMS } \\
\text { ncil uses collected taxes } \\
\text { ncessionaire (i.e. the } \\
\text { r) a subscription fee. } \\
\text { ste sales. }\end{array}$ & $\begin{array}{l}\text { - The City Cour } \\
\text { the Concessio } \\
\text { a subscription } \\
\text { - Recycled was }\end{array}$ & $\begin{array}{l}\text { ncil uses collected taxes to pay } \\
\text { naire (i.e. the server provider) } \\
\text { fee. } \\
\text { ste sales. }\end{array}$ \\
\hline $\begin{array}{l}\text { - Energy consumption and } \\
\text { environmental impact. }\end{array}$ & $\begin{array}{l}\text { - Energy consumption and env } \\
\text { impact, but lower than witho }\end{array}$ & $\begin{array}{l}\text { ivironmental } \\
\text { lout lor. }\end{array}$ & $\begin{array}{l}\text { SOCIAL \& EN } \\
\text { BENEFIT } \\
\text { - Job creation to } \\
\text { stimulates econ } \\
\text { - A clean city at } \\
\text { - Urban healthi } \\
\text { health problem }\end{array}$ & $\begin{array}{l}\text { WVIRONMENTAL } \\
\text { to manage the service } \\
\text { tomic activity. } \\
\text { attracts tourism. } \\
\text { iness reduces public } \\
\text { ms. }\end{array}$ & $\begin{array}{l}\text { - Lower servi } \\
\text { reduction. } \\
\text { - Quality job } \\
\text { service high } \\
\text { - Smart busin } \\
\text { in the city. } \\
\text { - A clean city } \\
\text { - Less energy } \\
\text { - Urban health } \\
\text { problems. }\end{array}$ & $\begin{array}{l}\text { ce cost should allow tax } \\
\text { creation to manage the } \\
\text { ly qualified). } \\
\text { hess ecosystem development } \\
\text { attracts tourism. } \\
\text { consumption. } \\
\text { hiness reduces public health }\end{array}$ \\
\hline
\end{tabular}

Then, the business model linked to the new system (Table 4) is compared with the one which has been operating so far:

- There is a small increase in financial costs for the service provider as it must invest to cover the costs of technology. However, the Cost Structure is lower because the total management costs are clearly smaller in the long term as the last public tender for this service showed. In other words, as the new technologies allow a more efficient management, the costs of the first public tender of the service that demanded the use of IoT technologies was tendered for a value of less than $20 \%$ with respect to the previous one, which was managed conventionally. As we take the point of view of aggregation actors, 2 points are allocated in this sub-parameter. Another 0.5 points are added due to the diversification of sources of costs as the service provider benefits from reduced fuel costs, human resources and other factors.

- The Revenue Streams do not change at all so 2 points are assigned in this parameter. 
- We believe that as Social and Environmental Costs, 0.5 points should be considered -due to the potential small reduction of employees in the service can damage social cohesion.

- The Social and Environmental Benefits add 1 point because these innovative technologies put Santander on the map as a city where the knowledge economy and productive innovation predominate; 0.5 points for the generation of talent for hiring highly qualified professionals to manage ICTs; 0.5 points for improving the quality of service for all citizens as it promotes social cohesion; and 1 point for the improvement in environmental sustainability and accessibility as lower consumption of $\mathrm{CO}_{2}$ and less traffic disruption are clear benefits of optimized vehicle routes.

- We give 0.5 points in the Value Proposition parameter because the necessity of improving the waste management service is permanent for city halls and citizens, nevertheless we do not consider it a problematic issue at this time; 0.5 points because people are always interested in improving waste management but do not claim massively for it; another 0.5 points because traffic congestion and environmental improvements are upgrades in the quality of life; 0.5 points because the service quality is slightly better than the former one; 1 point because the $20 \%$ reduction of the total cost of the service is an important saving for municipal budgets in such kind of projects.

- We added 5 points in the Customers parameter because the new service constitutes an important upgrade for all citizens.

The result of the application of this methodology can be easily visualized when captured in a radar chart. It is depicted in Figure 2.

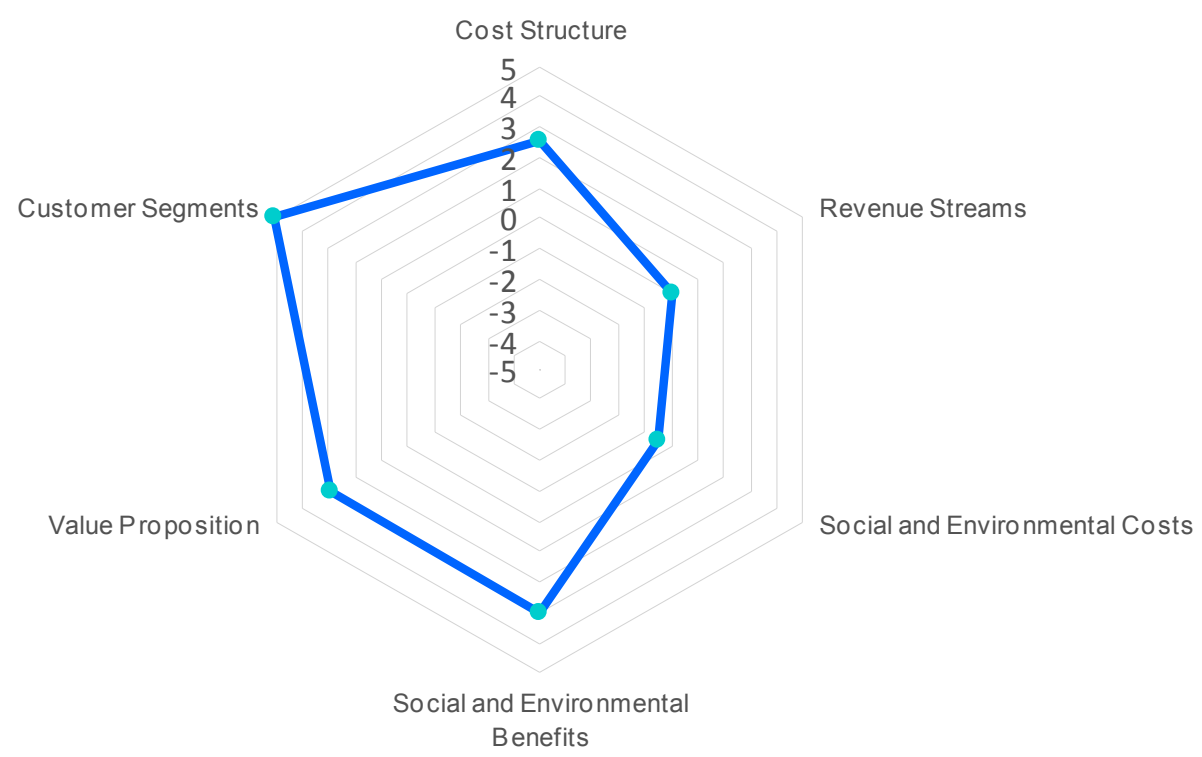

Figure 2. Radar chart of the Business Model Evaluation Tool of Santander's Waste Management System.

In case we want to get a pooled analysis to compare among various business models, we can apply the formula expressed below:

$$
\begin{gathered}
\mathrm{VBM}=(\mathrm{CE}+\mathrm{RE}-\mathrm{SEC}+\mathrm{SEB}+\mathrm{VP}) \times \mathrm{CS} \\
\mathrm{VBM}=(2.5+0-0.5+3+3) \times 5=45
\end{gathered}
$$


Table 4. Business Model Evaluation Tool linked to the Santander's Waste Management System.

\begin{tabular}{|c|c|c|c|}
\hline \multirow{2}{*}{\begin{tabular}{c|} 
Parameters \\
Cost Structure \\
\end{tabular}} & \multicolumn{2}{|r|}{ Potential Qualifications } & \multirow[t]{2}{*}{ Qualifications } \\
\hline & & & \\
\hline $\begin{array}{l}\text { Related to the service provided with the traditional system, } \\
\text { the cost offered with smart technologies is higher or lower? }\end{array}$ & $\begin{array}{c}-4 /-3 /-2 / \\
-1 / 0 /+1 /+2 /+3 /+4\end{array}$ & $\begin{array}{l}\text { (-4 For cost over } 50 \% \text { higher; }-3 \text { For cost between } 20 \% \text { and } 49 \% \\
\text { higher; }-2 \text { For cost between } 5 \% \text { and } 19 \% \text { higher; }-1 \text { For cost between } \\
0 \% \text { and } 4 \% \text { higher; } 0 \text { For the same cost; }+1 \text { For cost between } 0 \% \text { and } 4 \% \\
\text { lower; }+2 \text { For cost between } 5 \% \text { and } 19 \% \text { lower; }+3 \text { For cost between } \\
20 \% \text { and } 49 \% \text { lower; }+4 \text { For over } 50 \% \text { lower cost) }\end{array}$ & 2.0 \\
\hline $\begin{array}{l}\text { Related to the service provided with the traditional system, } \\
\text { the sources of costs are less, equal or more diversified? }\end{array}$ & $-1 / 0 / 1$ & ( -1 For less diversified; 0 For equal; and +1 For more diversified) & 0.5 \\
\hline & & & 2.5 \\
\hline \multicolumn{4}{|l|}{ Revenue Streams } \\
\hline $\begin{array}{l}\text { Related to the service provided with the traditional system, } \\
\text { the amount of revenue that this product/service will } \\
\text { generate more or less revenues for City Council and citizens? }\end{array}$ & $\begin{array}{c}-4 /-3 /-2 / \\
-1 / 0 /+1 /+2 /+3 /+4\end{array}$ & $\begin{array}{l}\text { (-4 For revenues below } 50 \% ;-3 \text { For revenues between } 20 \% \text { and } 49 \% \\
\text { lower; }-2 \text { For revenues between } 5 \% \text { and } 19 \% \text { lower; }-1 \text { For revenues } \\
\text { between } 0 \% \text { and } 4 \% \text { lower; } 0 \text { for the same revenues; }+1 \text { For revenues } \\
\text { between } 0 \% \text { and } 4 \% \text { greater; }+2 \text { For revenues between } 5 \% \text { and } 19 \% \\
\text { greater; }+3 \text { For revenues between } 20 \% \text { and } 49 \% \text { greater; }+4 \text { For } \\
\text { revenues over } 50 \% \text { greater) }\end{array}$ & 0.0 \\
\hline $\begin{array}{l}\text { Related to the service provided with the traditional system, } \\
\text { the sources of revenues are less, equal or more diversified? }\end{array}$ & $-1 / 0 /+1$ & ( -1 For less diversified; 0 For equal; and +1 For more diversified) & 0.0 \\
\hline & & & 0.0 \\
\hline Social and Environmental Costs & & & \\
\hline $\begin{array}{l}\text { To what extent it is negative to achieve the goal of being } \\
\text { an intermediate city that provides the backbone of the system } \\
\text { of the cities of the Cantabrian Sean and the European } \\
\text { Atlantic framework? }\end{array}$ & \multirow{5}{*}{$-1 /-0.5 / 0$} & \multirow{5}{*}{$\begin{array}{l}\text { ( }-1 \text { If the business model negatively affects this strategic objective; } \\
-0.5 \text { If it affects slightly to achieve that goal; and } 0 \text { if it does not affect) }\end{array}$} & 0.0 \\
\hline $\begin{array}{l}\text { To what extent it is negative to achieve the goal of being a city } \\
\text { which knowledge economy and productive } \\
\text { innovation prevail? }\end{array}$ & & & 0.0 \\
\hline $\begin{array}{l}\text { To what extent it is negative to achieve the goal of being } \\
\text { a creative city and productive of talent? }\end{array}$ & & & 0.0 \\
\hline $\begin{array}{l}\text { To what extent it is negative to achieve the goal of being } \\
\text { a City of commitment with citizenship and socially cohesive? }\end{array}$ & & & -0.5 \\
\hline $\begin{array}{l}\text { To what extent it is negative to achieve the goal of being } \\
\text { a sustainable, open and accessible city? }\end{array}$ & & & 0.0 \\
\hline
\end{tabular}


Table 4. Cont.

\begin{tabular}{|c|c|c|c|}
\hline Parameters & & $\begin{array}{l}\text { Potential Qualifications } \\
\end{array}$ & Qualifications \\
\hline & & & -0.5 \\
\hline \multicolumn{4}{|l|}{$\begin{array}{l}\text { Social and Environmental Benefits } \\
\end{array}$} \\
\hline $\begin{array}{l}\text { To what extent it contributes to achieve the goal of being } \\
\text { an intermediate city that provides the backbone of the system } \\
\text { of the cities of the Cantabrian Sean and the European } \\
\text { Atlantic framework? }\end{array}$ & \multirow{6}{*}{$0 /+0.5 /+1$} & \multirow{5}{*}{$\begin{array}{l}\text { ( } 0 \text { if the business model does not contribute to achieving this objective; } \\
+0.5 \text { If it contributes slightly to achieve that goal; and }+1 \text { if it } \\
\text { contributes a lot) }\end{array}$} & 0.0 \\
\hline $\begin{array}{l}\text { To what extent it contributes to achieve the goal of being } \\
\text { a city which knowledge economy and productive } \\
\text { innovation prevail? }\end{array}$ & & & 1.0 \\
\hline $\begin{array}{l}\text { To what extent it contributes to achieve the goal of being } \\
\text { a creative city and productive of talent? }\end{array}$ & & & 0.5 \\
\hline $\begin{array}{l}\text { To what extent it contributes to achieve the goal of being } \\
\text { a City of commitment with citizenship and socially cohesive? }\end{array}$ & & & 0.5 \\
\hline $\begin{array}{l}\text { To what extent it contributes to achieve the goal of being a } \\
\text { sustainable, open and accessible city? }\end{array}$ & & & 1.0 \\
\hline & & & 3.0 \\
\hline $\begin{array}{c}\text { Value Proposition } \\
\end{array}$ & & & \\
\hline $\begin{array}{l}\text { The product/service meets a need of City Council and } \\
\text { citizens? }\end{array}$ & \multirow{5}{*}{$0 /+0.5 /+1$} & \multirow{5}{*}{$\begin{array}{l}\text { ( } 0 \text { if the answer is No; }+0.5 \text { If the answer is eminently positive; and }+1 \\
\text { if the answer is clearly positive) }\end{array}$} & 0.5 \\
\hline Are the citizens interested in adopting this product/service? & & & 0.5 \\
\hline $\begin{array}{l}\text { Is this product/service a plausible improvement in the } \\
\text { quality of life of citizens? }\end{array}$ & & & 0.5 \\
\hline $\begin{array}{l}\text { Is the product/service of better quality than current } \\
\text { alternatives? }\end{array}$ & & & 0.5 \\
\hline $\begin{array}{l}\text { Is the product/service's price better price than current } \\
\text { alternatives? }\end{array}$ & & & 1.0 \\
\hline
\end{tabular}


Table 4. Cont

\begin{tabular}{|c|c|c|c|}
\hline Parameters & & Potential Qualifications & Qualifications \\
\hline & & & 3.0 \\
\hline \multicolumn{4}{|l|}{ Customer Segment } \\
\hline $\begin{array}{l}\text { Is the product/service potentially beneficial to at least } 1 \% \text { of } \\
\text { citizens? }\end{array}$ & \multirow{5}{*}{$0 /+1$} & \multirow{5}{*}{ ( 0 if the answer is negative; and +1 if the answer is positive) } & 1.0 \\
\hline $\begin{array}{l}\text { Is the product/service potentially beneficial to between } 1 \% \\
\text { and } 9 \% \text { of citizens? }\end{array}$ & & & 1.0 \\
\hline $\begin{array}{l}\text { Is the product/service potentially beneficial to between } 10 \% \\
\text { and } 24 \% \text { of citizens? }\end{array}$ & & & 1.0 \\
\hline $\begin{array}{l}\text { Is the product/service potentially beneficial to between } 25 \% \\
\text { and } 49 \% \text { of citizens? }\end{array}$ & & & 1.0 \\
\hline $\begin{array}{l}\text { Is the product/service potentially beneficial for more than } \\
50 \% \text { of citizens? }\end{array}$ & & & 1.0 \\
\hline $\begin{array}{l}\text { Is the product/service potentially detrimental to at least } 1 \% \\
\text { of citizens? }\end{array}$ & \multirow{6}{*}{$-1 / 0$} & \multirow{6}{*}{ ( 0 if the answer is negative; and -1 if the answer is positive) } & 0.0 \\
\hline $\begin{array}{l}\text { Is the product/service potentially detrimental to between } 1 \% \\
\text { and } 9 \% \text { of citizens? }\end{array}$ & & & 0.0 \\
\hline $\begin{array}{l}\text { Is the product/service potentially detrimental to between } \\
10 \% \text { and } 24 \% \text { of citizens? }\end{array}$ & & & 0.0 \\
\hline $\begin{array}{l}\text { Is the product/service potentially detrimental to between } \\
25 \% \text { and } 49 \% \text { of citizens? }\end{array}$ & & & 0.0 \\
\hline \multirow[t]{2}{*}{$\begin{array}{l}\text { Is the product/service potentially detrimental for more than } \\
50 \% \text { of citizens? }\end{array}$} & & & 0.0 \\
\hline & & & 5.0 \\
\hline
\end{tabular}




\subsection{Use Case: The Street Lighting Service of Santander}

The Santander street lighting use case has been used as an example to validate the Evaluation Tool. The business model of the new street lighting system has been compared with the conventional model that has been applied so far (Table 5).

Table 5. Comparison of the business models of the conventional street lighting infrastructure and the system integrating ICT infrastructure.

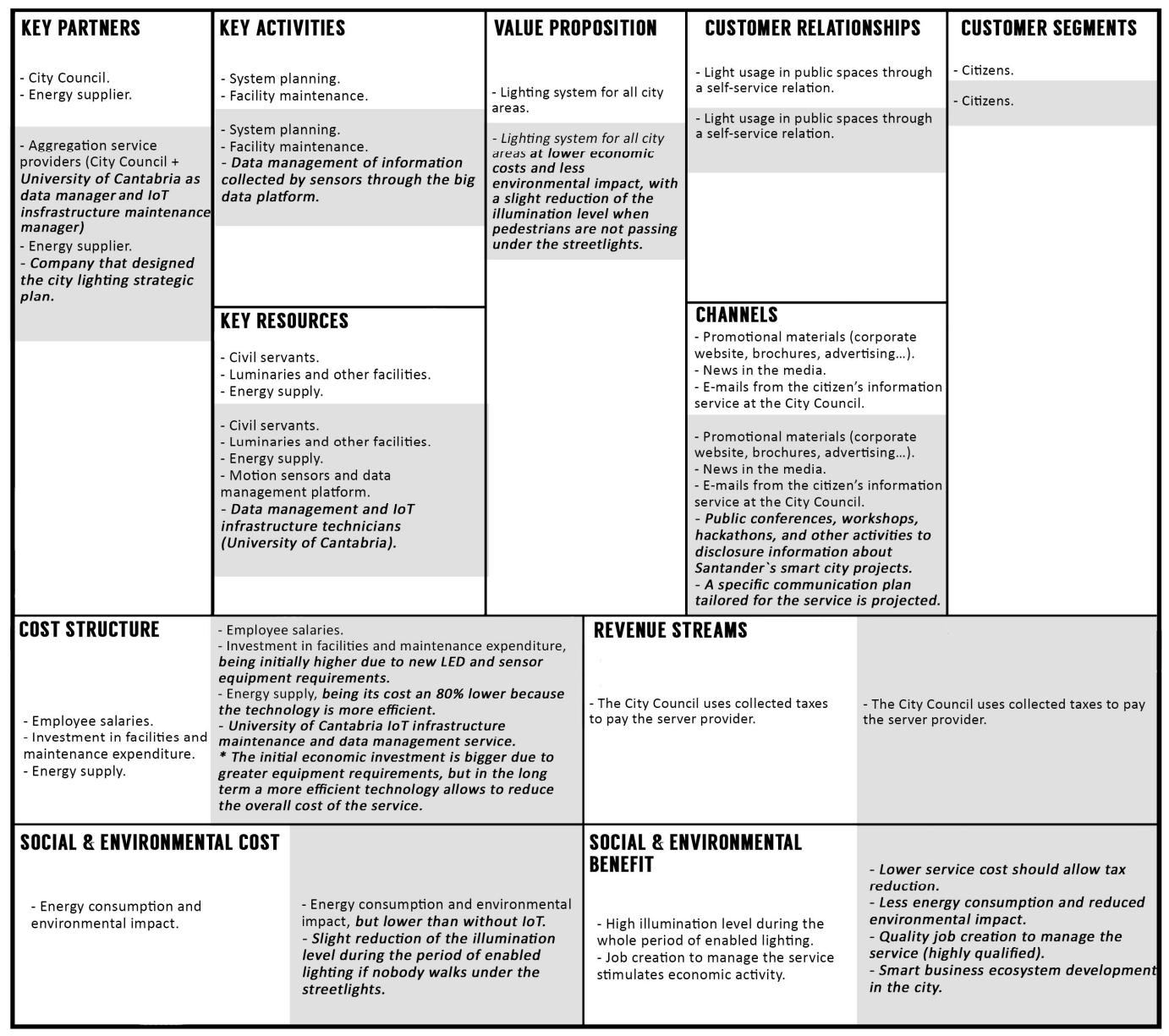

The evaluation of the business model of the new street lighting in relation to the one that has been developed so far is described in the following bullets (Table 6):

- An important initial investment is required and assumed by the concessionaire. However, the net Cost Structure is lower in the long term as the last public tender for this service showed. In other words, the first public tender of the service that demanded the use of LED and innovative ICT was tendered for a lower value with respect to the previous one, which was managed conventionally. As we take the point of view of aggregation actors, thus we give 2 points in this parameter.

- The Revenue Streams do not change at all so 0 points are assigned in this parameter.

- We believe that no Social and Environmental Costs stand out (0 points).

- A few factors are included between the Social and Environmental Benefits: 0.5 points because these innovative technologies contribute to put Santander on the map as a city where the knowledge economy and productive innovation predominate; 0.5 points for the generation of talent for hiring highly qualified professionals to manage ICTs; and 1 point for the sustainability supported by the reduction of energy consumption. 
- In the Value Proposition parameter, it is given: 0.5 points because it is always necessary to improve an important municipal service like this; 0.5 points because citizens are always interested on improving the service, even if they do not claim massively for it; and 1 point because the reduction of the total cost of the service is an important saving for municipal budgets in such kind of projects.

- We added 5 points in the Customers parameter because the new service constitutes an important upgrade for all citizens, at least in terms of public budget.

The result of the application of the methodology can be easily visualized when captured in a radar chart. It can be seen in the following graph (Figure 3).

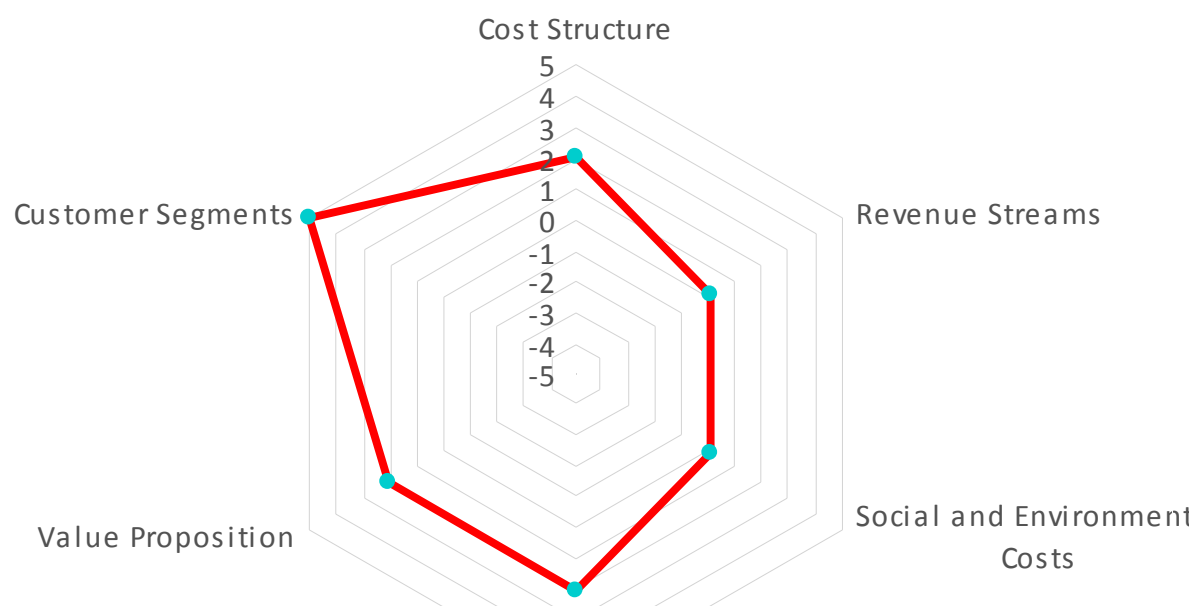

Social and Environmental

Benefits

Figure 3. Radar chart of the Business Model Evaluation Tool of Santander's street lighting system.

In case we want to get a pooled analysis to compare among various business models, we can apply the formula expressed below:

$$
\begin{gathered}
\mathrm{VBM}=(\mathrm{CE}+\mathrm{RE}-\mathrm{SEC}+\mathrm{SEB}+\mathrm{VP}) \times \mathrm{CS} \\
\mathrm{VBM}=(2+0+0+3+3) \times 5=40
\end{gathered}
$$


Table 6. Business Model Evaluation Tool of Santander's street lighting system.

\begin{tabular}{|c|c|c|c|}
\hline Parameters & Potential Qualifications & & Qualifications \\
\hline \multicolumn{4}{|l|}{ Cost Structure } \\
\hline $\begin{array}{l}\text { Related to the service provided with the traditional system, the cost offered with } \\
\text { smart technologies is higher or lower? }\end{array}$ & $\begin{array}{c}-4 /-3 /-2 / \\
-1 / 0 /+1 /+2 /+3 /+4\end{array}$ & $\begin{array}{l}\text { ((-4) For cost over } 50 \% \text { higher; }(-3) \text { For cost between } 20 \% \text { and } \\
49 \% \text { higher; }(-2) \text { For cost between } 5 \% \text { and } 19 \% \text { higher; } ;(-1) \text { For } \\
\text { cost between } 0 \% \text { and } 4 \% \text { higher; } 0 \text { For the same cost; }+1 \text { For cost } \\
\text { between } 0 \% \text { and } 4 \% \text { lower; }+2 \text { For cost between } 5 \% \text { and } 19 \% \\
\text { lower; }+3 \text { F) }\end{array}$ & 2.0 \\
\hline $\begin{array}{l}\text { Related to the service provided with the traditional system, the sources of costs } \\
\text { are less, equal or more diversified? }\end{array}$ & $-1 / 0 /+1$ & $\begin{array}{l}\text { ((-1) For less diversified; } 0 \text { For equal; and }+1 \text { For more } \\
\text { diversified) }\end{array}$ & 0.0 \\
\hline \multirow{2}{*}{\multicolumn{4}{|c|}{ Revenue Streams }} \\
\hline & & & \\
\hline $\begin{array}{l}\text { Related to the service provided with the traditional system, the amount of } \\
\text { revenue that this product/service will generate more or less revenues for City } \\
\text { Council and citizens? }\end{array}$ & $\begin{array}{c}-4 /-3 /-2 / \\
-1 / 0 /+1 /+2 /+3 /+4\end{array}$ & $\begin{array}{l}\text { ((-4) For revenues below } 50 \% ;(-3) \text { For revenues between } 20 \% \\
\text { and } 49 \% \text { lower; }(-2) \text { For revenues between } 5 \% \text { and } 19 \% \text { lower; } \\
(-1) \text { For revenues between } 0 \% \text { and } 4 \% \text { lower; } 0 \text { for the same } \\
\text { revenues; }+1 \text { For revenues between } 0 \% \text { and } 4 \% \text { greater; }+2 \text { For } \\
\text { revenues between } 5)\end{array}$ & 0.0 \\
\hline $\begin{array}{l}\text { Related to the service provided with the traditional system, the sources of } \\
\text { revenues are less, equal or more diversified? }\end{array}$ & $-1 / 0 / 1$ & $\begin{array}{l}((-1) \text { For less diversified; } 0 \text { For equal; and }+1 \text { For more } \\
\text { diversified) }\end{array}$ & 0.0 \\
\hline \multirow{2}{*}{\multicolumn{4}{|c|}{$\begin{array}{l}\text { Social and Environmental Costs } \\
\end{array}$}} \\
\hline & & & \\
\hline $\begin{array}{l}\text { To what extent it is negative to achieve the goal of being an intermediate city } \\
\text { that provides the backbone of the system of the cities of the Cantabrian Sean } \\
\text { and the European Atlantic framework? }\end{array}$ & \multirow{6}{*}{$-1 /-0.5 / 0$} & \multirow{6}{*}{$\begin{array}{l}\text { (( }(-1) \text { If the business model negatively affects this strategic } \\
\text { objective; }(-0.5) \text { If it affects slightly to achieve that goal; and } 0 \text { if } \\
\text { it does not affect) }\end{array}$} & 0.0 \\
\hline $\begin{array}{l}\text { To what extent it is negative to achieve the goal of being a city which knowledge } \\
\text { economy and productive innovation prevail? }\end{array}$ & & & 0.0 \\
\hline $\begin{array}{l}\text { To what extent it is negative to achieve the goal of being a creative city and } \\
\text { productive of talent? }\end{array}$ & & & 0.0 \\
\hline $\begin{array}{l}\text { To what extent it is negative to achieve the goal of being a City of commitment } \\
\text { with citizenship and socially cohesive? }\end{array}$ & & & 0.0 \\
\hline $\begin{array}{l}\text { To what extent it is negative to achieve the goal of being a sustainable, open and } \\
\text { accessible city? }\end{array}$ & & & 0.0 \\
\hline & & & 0.0 \\
\hline \multicolumn{4}{|l|}{ Social and Environmental Benefits } \\
\hline $\begin{array}{l}\text { To what extent it contributes to achieve the goal of being an intermediate city } \\
\text { that provides the backbone of the system of the cities of the Cantabrian Sean } \\
\text { and the European Atlantic framework? }\end{array}$ & \multirow{5}{*}{$0 /+0.5 /+1$} & \multirow{5}{*}{$\begin{array}{l}\text { ( } 0 \text { if the business model does not contribute to achieving this } \\
\text { objective; }+0.5 \text { If it contributes slightly to achieve that goal; } \\
\text { and }+1 \text { if it contributes a lot) }\end{array}$} & 0.0 \\
\hline $\begin{array}{l}\text { To what extent it contributes to achieve the goal of being a city which } \\
\text { knowledge economy and productive innovation prevail? }\end{array}$ & & & 0.5 \\
\hline $\begin{array}{l}\text { To what extent it contributes to achieve the goal of being a creative city and } \\
\text { productive of talent? }\end{array}$ & & & 0.5 \\
\hline $\begin{array}{l}\text { To what extent it contributes to achieve the goal of being a City of commitment } \\
\text { with citizenship and socially cohesive? }\end{array}$ & & & 0.0 \\
\hline $\begin{array}{l}\text { To what extent it contributes to achieve the goal of being a sustainable, open } \\
\text { and accessible city? }\end{array}$ & & & 1.0 \\
\hline
\end{tabular}


Table 6. Cont

\begin{tabular}{|c|c|c|c|}
\hline Parameters & Potential Qualifications & & Qualifications \\
\hline Value Proposition & & & \\
\hline The product/service meets a need of City Council and citizens? & \multirow{6}{*}{$0 /+0.5 /+1$} & \multirow{6}{*}{$\begin{array}{l}\text { ( } 0 \text { if the answer is } \mathrm{No} ;+0.5 \text { If the answer is eminently positive; } \\
\text { and }+1 \text { if the answer is clearly positive) }\end{array}$} & 0.5 \\
\hline Are the citizens interested in adopting this product/service? & & & 0.5 \\
\hline Is this product/service a plausible improvement in the quality of life of citizens? & & & 0.0 \\
\hline Is the product/service of better quality than current alternatives? & & & 0.0 \\
\hline \multirow[t]{2}{*}{ Is the product/service's price better price than current alternatives? } & & & 1.0 \\
\hline & & & 2.0 \\
\hline Customer Segment & & \multirow{6}{*}{ ( 0 if the answer is negative; and +1 if the answer is positive) } & \\
\hline Is the product/service potentially beneficial to at least $1 \%$ of citizens? & \multirow{5}{*}{$0 /+1$} & & 1.0 \\
\hline Is the product/service potentially beneficial to between $1 \%$ and $9 \%$ of citizens? & & & 1.0 \\
\hline $\begin{array}{l}\text { Is the product/service potentially beneficial to between } 10 \% \text { and } 24 \% \\
\text { of citizens? }\end{array}$ & & & 1.0 \\
\hline $\begin{array}{l}\text { Is the product/service potentially beneficial to between } 25 \% \text { and } 49 \% \\
\text { of citizens? }\end{array}$ & & & 1.0 \\
\hline Is the product/service potentially beneficial for more than $50 \%$ of citizens? & & & 1.0 \\
\hline Is the product/service potentially detrimental to at least $1 \%$ of citizens? & \multirow{5}{*}{$-1 / 0$} & \multirow{5}{*}{ ( 0 if the answer is negative; and ( -1 ) if the answer is positive) } & 0.0 \\
\hline $\begin{array}{l}\text { Is the product/service potentially detrimental to between } 1 \% \text { and } 9 \% \\
\text { of citizens? }\end{array}$ & & & 0.0 \\
\hline $\begin{array}{l}\text { Is the product/service potentially detrimental to between } 10 \% \text { and } 24 \% \\
\text { of citizens? }\end{array}$ & & & 0.0 \\
\hline $\begin{array}{l}\text { Is the product/service potentially detrimental to between } 25 \% \text { and } 49 \% \\
\text { of citizens? }\end{array}$ & & & 0.0 \\
\hline Is the product/service potentially detrimental for more than $50 \%$ of citizens? & & & 0.0 \\
\hline & & & 5.0 \\
\hline
\end{tabular}




\section{Discussion}

The creation of a methodology to assess the business models of public services can be useful for actors involved in urban management and social innovation in smart cities, including governments, businesses and citizens.

Nowadays, the Business Model Canvas is the most used framework for business model analysis among entrepreneurs, businessmen and researchers. Its simplicity and the well designed and executed communications actions are two key parts of its success. It seems reasonable to predict that a method based on the most used framework will have greater reception than an unknown system. In fact, several researchers have published amendments to the Canvas in order to analyze business models of specific activities. The methodology proposed in this research paper, the Business Model Evaluation Tool for Smart Cities, maintains the premises of simplicity and being based on the most used method. Being based in a widely adopted framework is an advantage related to the other existing method for evaluating business models in smart cities [35] because all the users of the Business Model Canvas will get familiar with this method quickly and easily. The Evaluation Tool also has a couple of important features in common with the existing method: both are based on qualitative indicators and take into account intangible factors that are key to evaluate smart cities' performance.

The Evaluation Tool introduced is a simple methodology that involves answering 29 simple questions using numerical values. It is a system with an organized structure that leads to measurable conclusions. As a specific methodology to be agreed upon by those responsible for assessing the different business models to be compared, it gives transparency to the process. In addition, its quick implementation allows evaluating and comparing two or more business models and making strategic decisions swiftly.

As described in the analysis of literature, the best-known frameworks to analyze business models focus on creating revenues and do not take into account other important values for society. Among these non-economic values are improving the citizen's quality of life or the care for the environment which are a priority for the government. The method we propose overcomes this obstacle by relying on the Non-Profit Business Model Canvas, an extension of the Business Model Canvas that takes social and environmental values into account.

The point of view of the aggregation has been taken as several members of the smart city ecosystem may take part in the design and implementation of public services. In the case studies described in this research paper, the aggregation of actors involved are the City Hall, responsible for providing the service in the most convenient manner; the company hired to manage the service; and the local university, which in these cases has been a fundamental part of the service design. In other business models, other different stakeholders are also involved, such as citizens who, for example, could provide essential information to manage the public service. Therefore, in order to analyze the business model, it is appropriate to take the viewpoint of the aggregation, even if some stakeholders are, in turn, part of the provision of service and customers thereof.

Evaluators may compare the results of the six parameters of the business models analyzed in the methodology or the entire model as well. In order to measure each business model as a whole, we have also created a formula to obtain a single numerical value model. This fact, which we call Value of the Business Model (VBM), is easily comparable with the value of other business models. As the VBM contains both objective and subjective indicators, it could be slightly biased, as it actually happens with many existing performance indicators in social sciences. In our method it specially happens when benchmarking cities with different strategic objectives as the 10 questions related to social and environmental costs and benefits change according to the strategic objectives of the city, so that the business models are consistent with the strategic plan of the city. In these specific situations, benchmarking VBM values which start from different questions could drive to slightly biased results. Nevertheless, it is still a method more accurate, transparent and fair than taking a guess.

Cities pose different objectives and pursue various positions; therefore, the aspects to be measured cannot be the same in all of them. The adaptation of the method to the strategic plan of the city 
promotes strategic planning and allows any user profile to use it. Obviously, previously there must be a public strategic plan of the city. In the event that it does not exist or is not public, evaluators must first agree on the strategic objectives to use as reference.

In governance, most decisions are debatable. But even having an unavoidable part of subjectivity, decision making through a transparent methodology leads to fairer decisions and strengthens citizens' confidence. Assessing the adequacy of a business model to the strategic plan of the city involves a subjective evaluation, and furthermore other parameters of the Evaluation Tool are also up to a certain point subjective. In fact, Cost Structure may be objective in the case of concessions of public services with a fixed price, but in other cases the value of this parameter is based on forecasts and, therefore, when using the Evaluation Tool a subjective factor is introduced. The grading of the parameters of Revenue Stream and Customer Segment also depend on forecasts which can be more or less successful, like it happens in all the businesses. As for the parameters of Social and Environmental Costs and Benefits, as well as the Value Proposition, their subjective nature emanates from the personal opinions of each member of the valuation panel. Some of the 29 questions that compose the Evaluation Tool include objective and subjective measures, prevailing the last one of them because the future performance of a business model obviously holds a heavy subjective component. In this sense, it is reasonable to suppose that a panel formed by diverse profiles should enrich the quality of the valuation and reduce its subjectivity. Despite the existence of a certain amount of subjectivity in the evaluation of business models with the Evaluation Tool, its use should remain useful for those who are faced with choosing a business model because it facilitates analysis and decision-making taking into account various perspectives, and enhances accountability and transparency. Business is not an exact science and, thus, both technical forecast and instinct are necessary. Evaluation tools may show results slightly biased and can be focused on selfish indicators, but they have their manifest advantages with respect to making at a guess.

As all members of the smart city ecosystem are potential developers of services and drivers of innovation, they are also potential users of the Evaluation Tool. This methodology meets this need as the profile of people who can use this methodology is heterogeneous: public managers, entrepreneurs who create an app, service concessionaires, etc.

The methodology presented in this paper not only has been validated through two case studies, but also has been reviewed by 11 experts who gave their recommendations. As it was reviewed by both researchers and professionals, we can assume that it can be applied both in the scientific and the professional fields. The validation through two case studies proves the applicability of the method to various different business models; in fact, it has been explicitly conceived to fit the different use cases. The Evaluation Tool is not only open to modifications to be adapted to all smart cities. In fact, this measurement methodology could also be applied to business models of other areas such as regional, national and international public administrations; NGOs; and even other for-profit organizations fully aware of the development of the communities where they operate.

\section{Conclusions, Limitations and Future Work}

New technologies open the door to innovative business models applied to public services offered in smart cities. This article addresses the growing need of assessing and comparing potential business models through a new method called the Business Model Evaluation Tool for Smart Cities. This method allows choosing the most appropriate one depending on the objectives of each city.

Any stakeholder may be interested in evaluating the most suitable business model for a public service of the smart city. Therefore, we have designed a methodology that any stakeholder can use. The fact that it has been reviewed by scientists and practitioners proves that it can be used by both communities. In addition, it is based on the Business Model, the most used framework for analyzing business models, which should facilitate its adoption.

The Business Model Evaluation Tool for Smart Cities is an organized and transparent system that facilitates the work of the evaluators of potential business models. The methodology is flexible enough 
to collect all the factors that may affect the business models of utilities used in smart cities and be adapted to the specific needs of each of these strategies. For its rapid implementation, this method allows to measure and compare two or more business models and make strategic decisions swiftly.

Forecasting future performance of a business models requires a subjective component and, thus, the Evaluation Tool lead to debatable decisions. Nevertheless, it facilitates decision making and enhances transparency and accountability.

This method has been designed specifically for smart cities; however, it could be adapted to assess business models of other areas such as public administrations of any level or even for-profit organizations which feel responsible for the development of the communities where they operate.

In order to design this methodology, we have developed constructive research with a heterogeneous mix of complementary methods: content analysis, in-depth interviews to 11 practitioners and researchers, and two case studies to validate the framework.

To conclude, the authors must point out that in spite of the extensive research work developed; this study has a few limitations: It would be convenient to validate the Evaluation Tool through various different case studies and interviewing more researchers and practitioners. Both issues will be addressed in future works.

Acknowledgments: We thank to the European Commission's H2020 Program, Organicity, GA-645198, for partially funding the research work carried out in this paper.

Author Contributions: R.D.-D., L.M. and D.P.-G. conceived and designed the experiments; R.D.-D. performed the experiments; R.D.-D. analyzed the data; R.D.-D., L.M. and D.P.-G. contributed reagents/materials/analysis tools; R.D.-D. wrote the paper.

Conflicts of Interest: The authors declare no conflict of interest.

\section{References}

1. Popescu, R.I. Study regarding the ways of measuring cities competitiveness. Econ. Ser. Manag. 2011, 14, 288-303.

2. Angel, S.; Parent, J.; Civco, D.L.; Blei, A.M. Making Room for a Planet of Cities; Lincoln Institute of Land Policy: Cambridge, MA, USA, 2011; pp. 1-77.

3. United Nations. Urban Planning for City Leaders, 2nd ed.; United Nations Human Settlements Programme: Nairobi, Kenya, 2013; p. 187.

4. Graham, S.; Marvin, S. Planning cyber-cities? Integrating telecommunications into urban planning. Town Plan. Rev. 1999, 70, 89-114. [CrossRef]

5. ITU-T Focus Group on Smart Sustainable Cities. Master Plan for Smart Sustainable Cities; ITU: Geneva, Switzerland, 2015.

6. Harrison, C.; Donnelly, I.A. A theory of smart cities. In Proceedings of the 55th Annual Meeting of the ISSS, Hull, UK, 17-21 July 2011; pp. 1-15.

7. Walravens, N.; Ballon, P. Platform Business Models for Smart Cities: From Control and Value to Governance and Public Value. IEEE Commun. Mag. 2013, 51, 72-79. [CrossRef]

8. Gil, O.; Navío, J.; Pérez de Heredia, M. ¿Cómo se Gobiernan las Ciudades?; Silva Editorial: Tarragona, Spain, 2015; p. 118.

9. Komninos, N.; Tsarchopoulos, P.; Kakderi, C. New Services Design for Smart Cities: A Planning Roadmap for User-Driven Innovation. In Proceedings of the 2014 ACM International Workshop on Wireless and Mobile Technologies for Smart Cities, Philadelphia, PA, USA, 11 August 2011; pp. 29-38.

10. Lanza, J.; Sánchez, L.; Muñoz, L.; Galache, J.A.; Sotres, P.; Santana, J.R.; Gutiérrez, V. Large-Scale Mobile Sensing Enabled Internet-of-Things Testbed for Smart City Services. Int. J. Distrib. Sens. Netw. 2015, 2015, 785061. [CrossRef]

11. Lee, J.H.; Hancock, M.G.; Hu, M.-C. Towards an effective framework for building smart cities: Lessons from Seoul and San Francisco. Technol. Forecast. Soc. Chang. 2013, 89, 80-99. [CrossRef]

12. Achaerandio, R.; Curto, J.; Bigliani, R.; Gallotti, G. Análisis de las Ciudades Inteligentes en España 2012-El Viaje a la Ciudad Inteligente; IDC: Madrid, Spain, 2012. 
13. Krčo, S.; Fernandes, J.; Sanchez, L. SmartSantander-A smart city experimental platform. Electrotech. Rev. 2013, 79, 3-6.

14. Zygiaris, S. Smart City Reference Model: Assisting Planners to Conceptualize the Building of Smart City Innovation Ecosystems. J. Knowl. Econ. 2013, 4, 217-231. [CrossRef]

15. Schaffers, H.; Komninos, N.; Pallot, M. Smart cities and the future internet: Towards cooperation frameworks for open innovation. In The Future Internet; Springer: Berlin/Heidelberg, Germany, 2011.

16. Gutiérrez, V.; Galache, J.A.; Sánchez, L. SmartSantander: Internet of things research and innovation through citizen participation. In The Future Internet; Springer: Berlin/Heidelberg, Germany, 2013; pp. 173-186.

17. Galache, J.A.; Gutiérrez, V.; Santana, J.R.; Sánchez, L.; Casanueva, J.; Sostres, P. SmartSantander: A joint service provision facility and experimentation-oriented testbed, within a smart city environment. In Proceedings of the Future Network \& Mobile Summit 2013, Lisbon, Portugal, 3-5 July 2013.

18. Sanchez, L.; Galache, J.A. SmartSantander: IoT experimentation over a smart city testbed. Comput. Netw. 2014, 61, 217-238. [CrossRef]

19. Díaz-Díaz, R.; Pérez-González, D. Implementation of Social Media Concepts for e-Government: Case Study of a Social Media Tool for Value Co-Creation and Citizen Participation. J. Organ. End User Comput. 2016, 28, 104-121. [CrossRef]

20. Dameri, R.P.; Ricciardi, F.; D'Auria, B. Knowledge and intellectual capital in smart city. In Proceedings of the 15th European Conference on Knowledge Management ECKM 2014, Santarém, Portugal, 4-5 September 2014; pp. 250-257.

21. Cosgrave, E.; Tryfonas, T.; Crick, T. The Smart City from a Public Value Perspective. In Proceedings of the 2014 Conference ICT for Sustainability, Stockholm, Sweden, 24-27 August 2014; p. 9.

22. Yamagata, Y.; Seya, H. Simulating a future smart city: An integrated land use-energy model. Appl. Energy 2013, 112, 1466-1474. [CrossRef]

23. Gall, F.L.; Chevillard, S.V.; Gluhak, A.; Walravens, N.; Xueli, Z.; Hadji, H.B. Benchmarking Internet of Things Deployment: Frameworks, Best Practices and Experiences; Modeling and Processing for Next-Generation Big-Data Technologies; Springer: Cham, Switzerland, 2011; Volume 4, pp. 473-496.

24. Osterwalder, A. The Business Model Ontology-A Proposition in a Design Science Approach; Université de Lausanne: Lausanne, Switzerland, 2004.

25. Solaimani, S.; Bouwman, H.; Itälä, T. Networked enterprise business model alignment: A case study on smart living. Inf. Syst. Front. 2015, 17, 871-887. [CrossRef]

26. Arribas-Bel, D.; Kourtit, K.; Nijkamp, P. Benchmarking of world cities through Self-Organizing Maps. Cities 2013, 31, 248-257. [CrossRef]

27. Branchi, P.; Fernández-Valdivielso, C.; Matias, I. Analysis Matrix for Smart Cities. Future Internet 2014, 6, 61-75. [CrossRef]

28. Caragliu, A.; del Bo, C.; Kourtit, K.; Nijkamp, P. Comparative performance assessment of Smart Cities around the North Sea basin. Netw. Ind. Q. 2011, 13, 15-17.

29. Debnath, A.K.; Chin, H.C.; Haque, M.M.; Yuen, B. A methodological framework for benchmarking smart transport cities. Cities 2014, 37, 47-56. [CrossRef]

30. Giffinger, R.; Haindlmaier, G.; Kramar, H. The role of rankings in growing city competition. Urban Res. Pract. 2010, 3, 299-312. [CrossRef]

31. Giffinger, R.; Haindlmaier, G. Smart cities ranking: An effective instrument for the positioning of cities? Archit. City Environ. 2010, 4, 7-26.

32. Pérez-González, D.; Díaz-Díaz, R. Public Services Provided with ICT in the Smart City Environment: The Case of Spanish Cities. J. Univ. Comput. Sci. 2015, 21, 248-267.

33. Theng, Y.-L.; Xu, X.; Kanokkorn, W. Towards the Construction of Smart City Index for Analytics (SM-CIA): Pilot-Testing with Major Cities in China Using Publicly Available Data. In Proceedings of the 2016 49th Hawaii International Conference on System Sciences (HICSS), Kauai, HI, USA, 5-8 June 2016; pp. 2964-2973.

34. Neirotti, P.; De Marco, A.; Cagliano, A.C.; Mangano, G.; Scorrano, F. Current trends in Smart City initiatives: Some stylised facts. Cities 2014, 38, 25-36. [CrossRef]

35. Walravens, N. Qualitative indicators for smart city business models: The case of mobile services and applications. Telecommun. Policy 2015, 39, 218-240. [CrossRef] 
36. Walravens, N. Mobile Business and the Smart City: Developing a Business Model Framework to Include Public Design Parameters for Mobile City Services. J. Theor. Appl. Electron. Commer. Res. 2012, 7, 121-135. [CrossRef]

37. Walravens, N. Case Study Validation of a Business Model Framework for Smart City Services: FixMyStreet and London Bike App. IT Converg. Pract. 2013, 1, 22-38.

38. Walravens, N. Validating a business model framework for smart city services: The case of fixmystreet. In Proceedings of the 27th International Conference on Advanced Information Networking and Applications Workshops (WAINA 2013), Barcelona, Spain, 23-24 December 2013; pp. 1355-1360.

39. Cocchia, A. Smart and digital city: A systematic literature review. In Smart City; Dameri, R.P., Rosenthal-Sabroux, C., Eds.; Springer: Cham, The Newtherlands, 2014; pp. 13-43.

40. Calzada, I.; Cobo, C. Unplugging: Deconstructing the Smart City. J. Urban Technol. 2015, 22, 23-43. [CrossRef]

41. Caragliu, A.; Del Bo, C.; Nijkamp, P. Smart Cities in Europe. J. Urban Technol. 2011, 18, 65-82. [CrossRef]

42. Harrison, C.; Eckman, B.; Hamilton, R.; Hartswick, P.; Kalagnanam, J.; Paraszczak, J.; Williams, P. Foundations for Smarter Cities. IBM J. Res. Dev. 2010, 54, 1-16. [CrossRef]

43. Albino, V.; Berardi, U.; Dangelico, R.M. Smart Cities: Definitions, Dimensions, Performance, and Initiatives. J. Urban Technol. 2015, 22, 3-21. [CrossRef]

44. Giffinger, R.; Pichler-Milanović, N. Smart Cities: Ranking of European Medium-Sized Cities; Centre of Regional Science, Vienna University of Technology: Vienna, Austria, 2007.

45. Abdoullaev, A. A Smart World: A Development Model for Intelligent Cities. In Proceedings of the 11th IEEE International Conference on Computer and Information Technology, Athens, GA, USA, 6-8 July 2011; pp. 1-28.

46. Koppenjan, J.; Enserink, B. Public-private partnerships in urban infrastructures: Reconciling private sector participation and sustainability. Public Adm. Rev. 2009, 69, 284-296. [CrossRef]

47. Bakici, T. State of the Art-Open Innovation in Smart Cities; ESADE: Barcelona, Spain, 2011.

48. Segelstrom, F. Stakeholder Engagement for Service Design: How Service Designers Identify and Communicate Insights; Linkoping University Electron Press: Linköping, Sweden, 2013; pp. 1-210.

49. Linders, D. From e-government to we-government: Defining a typology for citizen coproduction in the age of social media. Gov. Inf. Q. 2012, 29, 446-454. [CrossRef]

50. Strandvik, T.; Holmlund, M.; Edvardsson, B. Customer needing: A challenge for the seller offering. J. Bus. Ind. Mark. 2012, 27, 132-141. [CrossRef]

51. Neely, A.; Gregory, M.; Platts, K. Performance measurement system design: A literature review and reseach agenda. Int. J. Oper. Prod. Manag. 1995, 15, 80-116. [CrossRef]

52. Wouters, M. A developmental approach to performance measures-Results from a longitudinal case study. Eur. Manag. J. 2009, 27, 64-78. [CrossRef]

53. Lohman, C.; Fortuin, L.; Wouters, M. Designing a performance measurement system: A case study. Eur. J. Oper. Res. 2004, 156, 267-286. [CrossRef]

54. Bremser, W.G.; Chung, Q.B. A framework for performance measurement in the e-business environment. Electron. Commer. Res. Appl. 2005, 4, 395-412. [CrossRef]

55. Kaplan, R.S.; Norton, D.P. Putting the Balanced Scorecard To Work. Harv. Bus. Rev. 1993, 71, $134-142$.

56. Lawrie, G.; Kalff, D.; Andersen, H. Balanced Scorecard and Results-Based Management Convergent performance management systems. In Proceedings of the 3rd Annual Conference on Performance Measurement and Management Control, The European Institute for Advanced Studies in Management, Nice, France, 22-23 September 2005.

57. Asian Development Bank (ADB). An Introduction to Results Management; Asian Development Bank: Metro Manila, Philippines, 2006.

58. Hood, C. The "New Public Management" in the 1980s: Variations on a theme. Account. Organ. Soc. 1995, 20, 93-109. [CrossRef]

59. Pattaro, A.F.; Tripi, S. (Re) building a Smart City. The role of local ICT-based services in emergency response and recovery. The case of earthquakes in Emilia-Romagna region. In Proceedings of the PSG I on Information And Communications Technologies in Public Administration, Edinburgh, UK, 11-13 September 2013; pp. 1-17.

60. Hefetz, A.; Warner, M. Privatization and its reverse: Explaining the dynamics of the government contracting process. J. Public Adm. Res. Theory 2004, 14, 171-190. [CrossRef] 
61. Sanderson, I. Evaluation, learning and the effectiveness of public services: Towards a quality of public service model. Int. J. Public Sect. Manag. 1996, 9, 90-108. [CrossRef]

62. Andrews, R.; van de Walle, S. New Public Management and Citizens' Perceptions of Local Service Efficiency, Responsiveness, Equity and Effectiveness. Public Manag. Rev. 2013, 15, 762-783. [CrossRef]

63. Clarke, J. Performing for the Public: Doubt, Desire, and the Evaluation of Public Services. In The Values of Bureaucracy; OUP: Oxford, UK, 2005; pp. 211-232.

64. Ruíz López, J.; Cuellar Martín, E.; del Pino Matute, E. Guía Para la Evaluación de la Calidad de Los Servicios Públicos; FUCOVASA: Madrid, Spain, 2008.

65. Mackay, K.; Picciotto, R.; Bairs, M.; Shand, D.; Divorski, S.; Rist, R.C.; Leeuw, F.; Marcel, M.; Barbarie, A.; Brushett, S.; et al. Public Sector Performance: The Critical Role of Evaluation. In Public Sector Performance: The Critical Role of Evaluation; Mackay, K., Ed.; The World Bank: Washington, DC, USA, 1998; pp. 1-113.

66. Weiss, C.H. Evaluation: Methods for Studying Programs and Policies; Prentice Hall: Englewood Cliffs, NJ, USA, 1998; p. 372.

67. Torres Fragoso, J. Posibilidades, logros y desafíos en la implementación de modelos de calidad en los gobiernos latinoamericanos. Estud. Gerenc. 2011, 27, 33-57. [CrossRef]

68. Dyllick, T.; Hockerts, K. Beyond the Business Case for Corporate Sustainability. Bus. Strategy Environ. Bus. Strat. Environ. 2002, 11, 130-141. [CrossRef]

69. Benington, J.; Moore, M.H. Public Value: Theory and Practice; Palgrave Macmillan: Basingstoke, UK, 2011; p. 314.

70. Veenhoven, R. Why social policy needs subjective indicators. Soc. Indic. Res. 2002, 58, 33-45. [CrossRef]

71. Jerman, D.; Bruno, Z. Model of marketing communications effectiveness in the Business-To-Business markets. Econ. Res. 2012, 25, 364-388. [CrossRef]

72. Zhang, S.; Yang, H.; Singh, L. Measuring quality of life: Economic, social, and subjective indicators. Soc. Indic. Res. 1997, 40, 189-216.

73. Zuiker, V.S.; Lee, Y.G.; Olson, P.D.; Danes, S.M.; Van Guilder Dik, A.N.; Jo Katras, M. Business, family, and resource intermingling characteristics as predictors of cash flow problems in family-owned businesses. J. Financ. Couns. Plan. 2002, 13, 65-83.

74. Olson, P.D.; Zuiker, V.S.; Danes, S.M.; Stafford, K.; Heck, R.K.Z.; Duncan, K.A. The impact of the family and the business on family business sustainability. J. Bus. Venture 2003, 18, 639-666. [CrossRef]

75. Torrubiano Galante, J.; Fernández Velasco, D.; González Miguel, D. Guía de Modelos de Evaluación Para la Administración Local; Agencia Estatal para la Evaluación de las Políticas Públicas y la Calidad de los Servicios, Ministerio de Política Territorial y Administración Pública: Madrid, Spain, 2011.

76. Coats, D.; Passmore, E. Public Value: The Next Steps in Public Service Reform; The Work Foundation: London, UK, 2008.

77. Kourtit, K.; Nijkamp, P.; Suzuki, S. The rat race between world cities: In search of Exceptional Places by means of super-efficient data development analysis. Comput. Environ. Urban Syst. 2013, 38, 67-77. [CrossRef]

78. Okulicz-Kozaryn, A. City Life: Rankings (Livability) Versus Perceptions (Satisfaction). Soc. Indic. Res. 2011, 110, 433-451. [CrossRef]

79. Schwarz, N. Urban form revisited-Selecting indicators for characterising European cities. Landsc. Urban Plan. 2010, 96, 29-47. [CrossRef]

80. Shen, L.-Y.; Jorge Ochoa, J.; Shah, M.N.; Zhang, X. The application of urban sustainability indicators-A comparison between various practices. Habitat Int. 2011, 35, 17-29. [CrossRef]

81. Giffinger, R.; Gudrun, H. Smart cities ranking: An effective instrument for the positioning of the cities? In Proceedings of the 5th International Conference Virtual City and Territory, Barcelona, Spain, 2-4 June 2009; pp. 703-714.

82. Paroutis, S.; Bennett, M.; Heracleous, L. A strategic view on smart city technology: The case of IBM Smarter Cities during a recession. Technol. Forecast. Soc. Chang. 2013, 89, 262-272. [CrossRef]

83. Mulligan, C.E.A.; Olsson, M. Architectural implications of smart city business models: An evolutionary perspective. IEEE Commun. Mag. 2013, 51, 80-85. [CrossRef]

84. Marolt, M.; Maletič, D.; Borštnar, M.K.; Lenart, G.; Pucihar, A. Comparative analysis of business model ontologies. In Proceedings of the 35th International Conference on Organizational Science Development, Portorož, Slovenia, 16-18 March 2016; p. 15. 
85. Pateli, A.G.; Giaglis, G.M. A framework for understanding and analysing e-business models. In Proceedings of the 16th Bled Electronic Commerce Conference eTransformation Bled, Bled, Slovenia, 9-11 June 2003.

86. McGrath, R.G. Business models: A discovery driven approach. Long Range Plan. 2010, 43, 247-261. [CrossRef]

87. Aljēna, A. Business model designing tool-Filling the gap between philosophy and reality. In Innovative Approaches to Business Education Selected Issues; Zięba, M., Zięba, K., Eds.; Via University College: Aarhus, Denmark, 2014; pp. 7-19.

88. Osterwalder, A.; Pigneur, Y. Business Model Generation: A Handbook for Visionaries, Game Changers, and Challengers; Self Published: Amsterdam, The Netherlands, 2010.

89. Birchall, D.; Chanaron, J.-J.; Tovstiga, G.; Hillenbrand, C. Innovation performance measurement: Current practices, issues and management challenges. Int. J. Technol. Manag. 2011, 56, 1-20. [CrossRef]

90. Wirtz, B.W.; Göttel, V.; Daiser, P. Business Model Innovation: Development, Concept and Future Research Directions. J. Bus. Model. 2016, 4, 1-28.

91. Osterwalder, A.; Pigneur, Y.; Tucci, C.L. Clarifying business models: Origins, present, and future of the concept. Commun. Assoc. Inf. Syst. 2005, 16, 1-25.

92. Ojasalo, K.; Ojasalo, J. Adapting business model thinking to service logic: An empirical study on developing a service design tool. In The Nordic School, Alternative Perspectives on Marketing and Service Management; Gummerus, J., Von Koskull, C., Eds.; Hanken School of Economics: Helsinki, Finland, 2015; pp. 309-333.

93. Weiller, C.; Neely, A. Business Model Design in an Ecosystem Context; University of Cambridge: Cambridge, UK, 2013.

94. Osterwalder, A.; Pigneur, Y.; Bernarda, G.; Smith, A. Value Proposition Design: How to Create Products and Services Customers Want; Wiley: New York, NY, USA, 2014; p. 320.

95. Ver Loren van Themaat, T.; Schutte, C.S.; Lutters, D.; Kennon, D. Designing a framework to design a business model for the bottom of the pyramid population. S. Afr. J. Ind. Eng. 2013, 24, 190-204. [CrossRef]

96. Heikkilä, M.; Solaimani, S.; Soudunsaari, A.; Hakanen, M.; Kuivaniemi, L.; Suoranta, M. Performance Estimation of Networked Business Models: Case Study on a Finnish eHealth Service Project. J. Bus. Model. 2014, 2, 71-88.

97. Busi, M.; Bititci, U.S. Collaborative performance management: Present gaps and future research. Int. J. Product. Perform. Manag. 2006, 55, 7-25. [CrossRef]

98. Voelpel, S.C.; Leibold, M.; Eckhoff, R.A. The tyranny of the Balanced Scorecard in the innovation economy. J. Intellect. Cap. 2006, 7, 43-60. [CrossRef]

99. Faber, E.; Ballon, P.; Bouwman, H.; Haaker, T. Designing business models for mobile ICT services. In Proceedings of the 16th Bled Electronic Commerce Conference eTransformation, Bled, Slovenia, 9-11 June 2003; pp. 1-14.

100. Sun, Y.; Yan, H.; Lu, C.; Bie, R.; Thomas, P. A holistic approach to visualizing business models for the internet of things. Commun. Mob. Comput. 2012, 1, 4. [CrossRef]

101. Westerlund, M.; Leminen, S.; Rajahonka, M. Designing Business Models for the Internet of Things. Technol. Innov. Manag. Rev. 2014, 4, 5-14.

102. Fugl, K.L. Business Model Framework Proposal for Internet of Things; Copenhaguen Business School: Frederiksberg, Denmark, 2015.

103. Turber, S.; Brocke, J.; Gassmann, O.; Fleisch, E. Designing Business Models in the Era of Internet of Things. In Advancing the Impact of Design Science: Moving from Theory to Practice; Chiarini Tremblay, M., VanderMeer, D., Rothenberger, M., Gupta, A., Yoon, V., Eds.; Springer: Miami, FL, USA, 2014; pp. $17-31$.

104. Bélissent, J.; Mines, C.; Radcliffe, E.; Darashkevich, Y. Getting Clever About Smart Cities: New Opportunities Require New Business Models; Forrester: Cambridge, MA, USA, 2010.

105. Kuk, G.; Janssen, M. The Business Models and Information Architectures of Smart Cities. J. Urban Technol. 2011, 18, 39-52. [CrossRef]

106. Molinari, F. Innovative business models for smart cities: Overview of recent trends. In Proceedings of the European Conference on e-Government (ECEG), 12th European Conference on e-Government, ECEG 2012, Barcelona, Spain, 14-15 June 2012; pp. 483-492.

107. Silva, E.M.; Maló, P. IoT Testbed Business Model. Adv. Internet Things 2014, 4, 37-45. [CrossRef]

108. Deandres, N. Leveraging Applicable Business Models for IoT Enabled Service Solutions in the Downstream Automotive Supply Chain; Royal Institute of Technology (KHT): Stockholm, Sweden, 2014. 
109. Walravens, N. The city as a platform: A Case-based Exploration of Mobile Service Platform Types in the Context of the City. In Proceedings of the BMMP 2011 Third International Workshop on Business Models for Mobile Platforms-Access and Competitiveness in Multi-Sided Markets, Berlin, Germany, 7 October 2011; IEEE: Berlin, Germany, 2011; pp. 283-288.

110. Malmström, A.; Johansson, J.; Chronér, D.; Bouckaert, S.; Martinez Garcia, S.; Potts, M.; Quetin, G.; Riepula, M.; Grace, P.; Nilsson, M.; et al. FIRE Collaboration Models; European Commission: Brussels, Belgium, 2015.

111. Ballon, P. Business modelling revisited: The configuration of control and value. Info 2007, 9, 6-19. [CrossRef]

112. Mora Penagos, W.M.; Parga Lozano, D.L. Tramas Histórico-Epistemológicas en la Evolución de la Teoría Estructural en Química Orgánica. TED Tecné Episteme y Didaxis 2007, 21, 100-118.

113. Kasanen, E.; Lukka, K.; Siitonen, A. The Constructive Approach in Management Accounting Research. J. Manag. Account. Res. 1993, 5, 243-264.

114. Lehtiranta, L.; Junnonen, J.-M.; Kärnä, S.; Pekuri, L. The Constructive Research Approach: Problem Solving for Complex Projects. In Designs, Methods and Practices for Research of Project Management; Routledge: London, UK, 2015; p. 520.

115. Berelson, B. Content Analysis in Communication Research; The Free Press: Glencoe, IL, USA, 1952; p. 220.

116. Hernández, R.; Fernández, C.; Baptista, P.; Hernandez Sampieri, R.; Fernandez Collado, C.; del Baptista Lucio M, P. Metodología de la Investigación; McGraw Hill: Mexico City, Mexico, 1991; p. 518.

117. Lombardi, P.; Giordano, S.; Caragliu, A.; del Bo, C.; Deakin, M.; Nijkamp, P.; Kourtit, K.; Farouh, H. An Advanced Triple-Helix Network Model for Smart Cities Performance. In Green and Ecological Technolongies Urban Planning; Vrije Universiteit Amsterdam: Amsterdam, The Netherlands, 2011.

118. Profile of the Interviewees. Available online: http://personales.unican.es/perezd/EnergiesSupplementaryMaterials. htm (accessed on 31 January 2017).

119. Bogner, A.; Littig, B.; Menz, W. Interviewing Experts; Palgrave Macmillan: New York, NY, USA, 2009 ; p. 30.

120. Rathbun, B.C. Interviewing and Qualitative Field Methods: Pragmatism and Practicalities. In The Oxford Handbook of Political Methodology; Box-Steffensmeier, J.M., Brady, H.E., Collier, D., Eds.; Oxford University Press: New York, NY, USA, 2008.

121. Eisenhardt, K.M.; Graebner, M.E. Theory building from cases: Opportunities and challenges. Acad. Manag. J. 2007, 50, 25-32. [CrossRef]

122. Baby, M.J.; Londoño, J.J.G. Las P's de Mercadeo Algunas Precisiones; AD-Minister, Universidad EAFIT: Medellín, Colombia, 2008; pp. 149-161.

123. Yin, R.K. Case Study Research: Design And Methods; Sage Publications: Thousand Oaks, CA, USA, $1994 ;$ p. 171.

124. Ayuntamiento de Santander. Plan Estratégico Santander 2020; Ayuntamiento de Santander: Cantabria, Spain, 2011.

(C) 2017 by the authors. Licensee MDPI, Basel, Switzerland. This article is an open access article distributed under the terms and conditions of the Creative Commons Attribution (CC BY) license (http:/ / creativecommons.org/licenses/by/4.0/). 